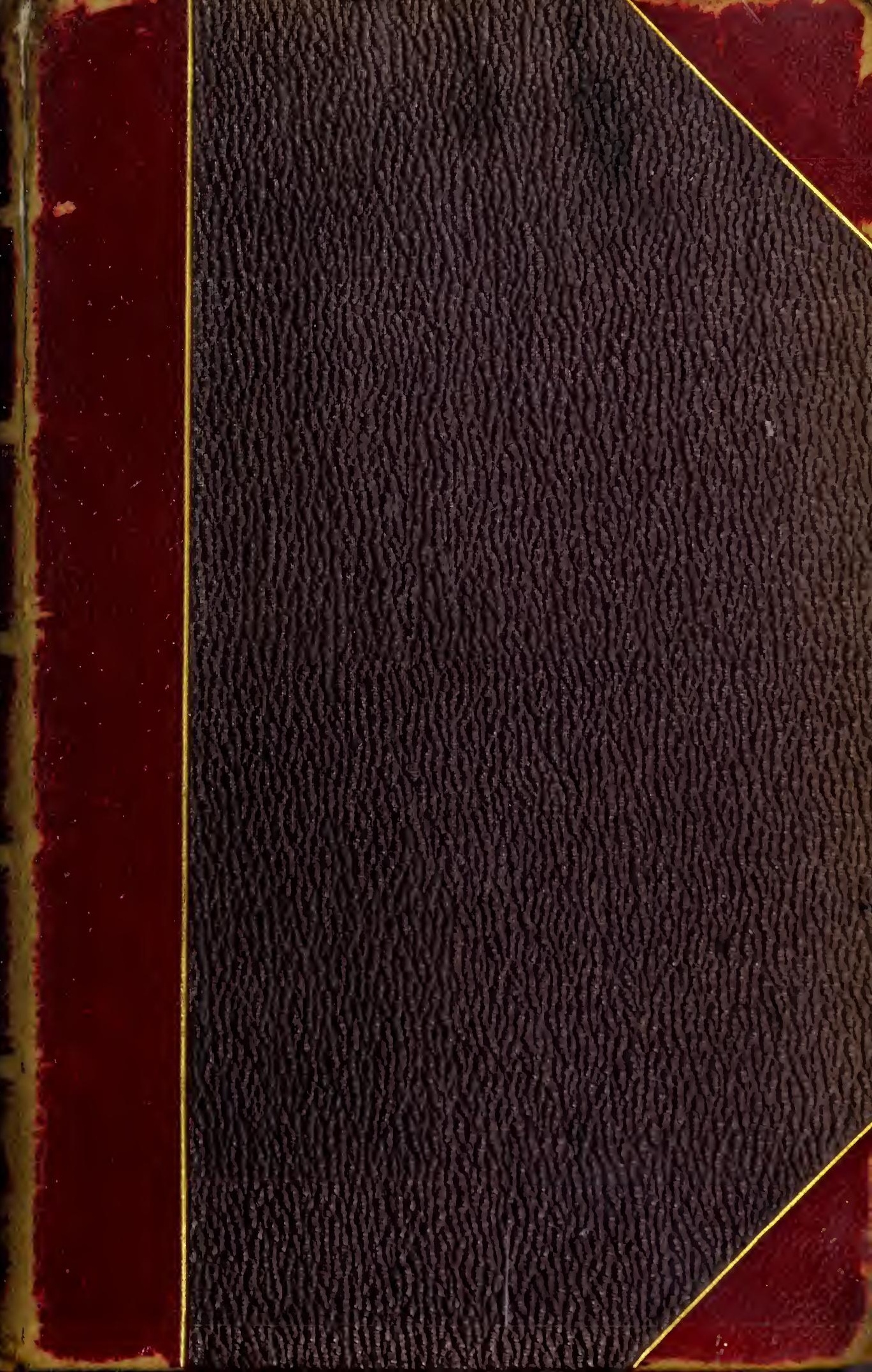




\section{CORNISH FAUNA;}

BEING A COMPENDIUMI

OF THE

\section{NATURAL HISTORY}

of

\section{THE COUNTY,}

Intended to form a Companion to the Collection in the Museum of the Royal Institution of Cornwall.

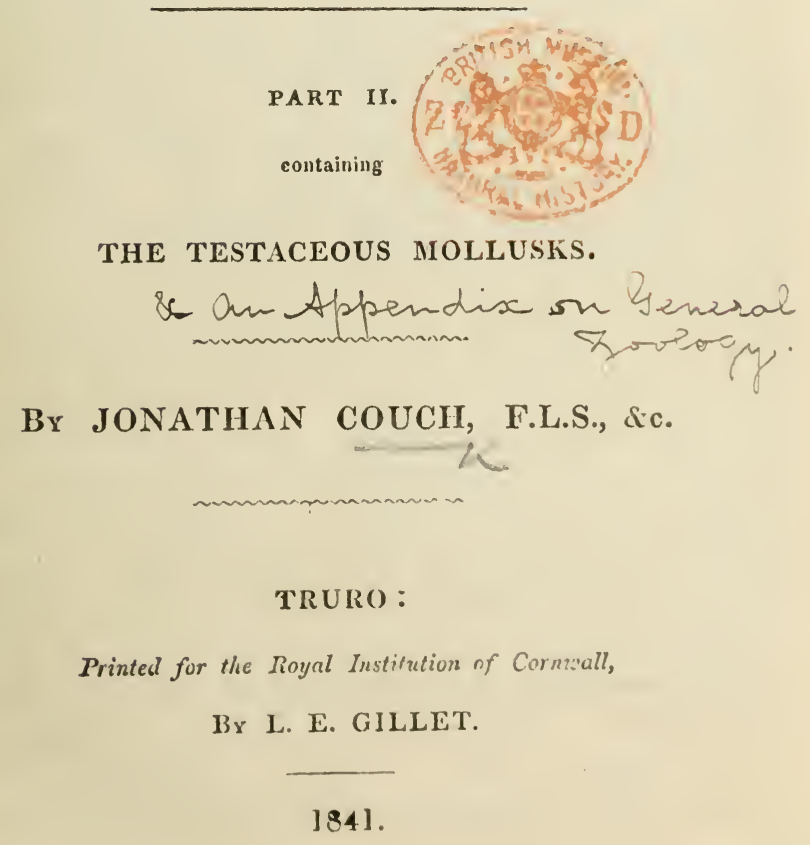





\section{IN'TRODUCTION.}

Linneus in his system of nature, united all Animals destitute of a spinal column and articulated limbs, into a single class, of which Testacea, or creatures having an external shell constituted an important division; but since his time the researches of Naturalists have proved, that such an arrangement is inconsistent with natural order.

Of the Mollusca or soft bodied animals, comprizing within it this entire group, nearly all have a developement of the skin which covers their body, and which bears more or less resemblance to a mantle. The naked Mollusca are those in which the mantle is simply membranous or fleshy; most frequently however, one or several layers of a substance more or less hard, is formed in its thickness, and increases in solidity as well as in extent, because the newer deposits always overlap the old ones. When this substance remains covered by the thickness of the mantle, it is still the custom to call the animals naked Mollusca. More generally however, it becomes so much developed, that the animal finds shelter beneath it; and the covering is then termed a shell: the creature being denominated Testaceous, or in common language, a shell fish. It is rare however, to find a shell in which some filmy portion of the soft animal substance with which 
the testaceous layer alternates, does not appear the external substance; but this Epidermis is no thin and brittle; and soon disappears under the friction to which most shell fish are exposed.*

In the opinion of physiologists then, a shell is regarded as simply a portion, the external skeleton, of an animal; and the generic character of the molluscous inhabitant is estimated by the preponderance of its various parts.

In forming an arrangement designed to embrace the natural affinities, this is indeed the only method which can be adopted. That of Lamarck is entirely built on it; and as the classitication of this eminent Naturalist is now chiefly followed in England: the shells of the British Museum being arranged by it, as well as the small collection presented to the Museum of the Royal Institution of Cornwall by the kindness of Sir Charles Lemon, Bart., M.P., it is judged proper that the present work, and the classification of the native specimens deposited in the Museum at Truro in illustration of it, should not form a departure from it.

Yet it must not be concealed that there are some things in the arrangement of Lamarck, which display an imperfection that will probably one day be fatal to it; and one especially, which it is surprizing should ever have been tolerated. For however convenient it may be to the philosophic student to begin his enquiries with the lowest forms, and in the examination to travel upward to the more complicated organization; yet having attained his results, it will scarcely be judged consistent with nature, to give those lower forms a permanent place at the head of the table. Man, rather than the Monad, should be at the head of Creation.

* Curier's Animal Kingdom. 
Another objection will strike the mind of such as may seek their occupation or amusement in examining the more solid forms contained in the Museum. As the modern classification arranges in close connection the Molluscs which may possess or are deprived of, a testaceous covering, or in which the shells, taken alone, may appear of very different forms, a discordancy may appear which shall seem far removed from our ideas of relationship in nature. The natural affinities, however, are more dependant on the soft than the solid portions, although unhappily the art has not yet been found, of preserving the latter in a state fit for examination. In some instances also, the shell alone is known to Naturalists: the inhabitant never having fallen in the way of an observer. But to obviate as much as possible all the difficulty likely to be thus encountered; and more especially for the benefit of those who, feeling an interest in the subject, may yet discover the philosophic arrangement to be rather an hindrance than an assistance, an attempt is here made to combine the spirit of the Linnean method with the arrangement of Lamarck, on which the work is founded. The manner of acquiring information may, and frequently ought to be, different from that in which it is retained; and Mr. Bicheno (Trans. Lin. Soc. vol. 15,) has shown how well fitted in this respect an artificial method is, to lead to the more easy and perfect acquisition of the natural.

It is with a view to this, that a rough outline of an arrangement is subjoined, by which it is hoped the student will be assisted in lis endeavour to discover the place of a shell, the scientific name of which may be unknown to him. The distinction of kindred species, however, can only be made, by reference to good figures, combined 
with accurate descriptions; the best or most easily accessible of which are given in the eunmeration of each separate species, but of which those of Montagu are most earnesly recommended to the student. To the names of all the shells of which specimens are preserved in the Museum of the Royal Institution, a star is affixed, as in the first Part of the Cornish Fauna; and for the remainder the individual authority is given: in doing which it has been judged more proper to suffer the omission of some species of which there might be little doubt, rather than to insert any on insufficient authority. But notwithstanding the efforts which the Author has made to obtain specimens in their native abodes, and the kind assistance of some friends, whose names are partly acknowledged when speaking of the shells for which the acknowledgement is due, still to render the Fauna in this Department complete will require the contribution of several hands; for in the course of his researches the Author has found, that a small extent of coast will sometimes present a change of species; and some which are rare in one district, shall occur in abundance in another. 


\section{S U M M A R Y}

OF THE

\section{GENERA OF CORNISH TESTACEOUS HOLLUSCS.}

SEDENTARY ANNULATA: With tubes or cases, encrusted with grains of sand and fragnents of shells; or solid, calcareous and homogenous. This order comprizes Dentalium, Sabellaria, Terebella, Amphitrite, Spirorbis, Serpula, Vermilia. Vermetus much resembles the Serpulaceæ, but is separated on account of the different structure of the animal.

CIRRHIPEDA, OR BARNACLES ; With many valves or plates, sessile or on a footstalk. From an opening capable of being closed proceed many slender, jointed, fringed tendrils, which are organs of prehen. sion. It comprizes Tubicinella, Balanus, Acasta, Creusia, Pyrgoma, which are sessile; and, with footstalks, the Genera Anatifera and Pollicipes.

CONCHIFERA or BIVALVES: With two principal valves or plates united by a hinge or ligament; and sometimes with accessary plates not belonging to the valves. It is divided into two orders; Conchifera Bimusculosa, with two internal separate and lateral muscular impressions; and Conchifera Unimusculosa, with only one muscle, which appears to pass through the body: the impression being about the centre of the shell.

The first order, C. Bimusculosa, comprizes four Sections,

C. Crassipeda : The shell when shut, gaping at the sides: Comprizing the Genera Teredo, Pholas, Gastrochæena, Solen, Mya, Anatina.

C. 'Tenupeda: Gaping of the shell at the sides generally little: Comprizing the Genera Lutraria, Mactra, Amphiclesma, Corbula, Saxicava, Venerirupis, Sanguinolaria, Psamonobia, Telliua, Lucina, Donax, Capsa, Crassina.

C. Lameripeda: Gaping none, but it is chiefly distinguished by the structure of the aninal : the foot being broad and thiu : Comprizing the Genera Cyclas, Pisirlinm, Cyprina, Cytheræa, Venus, Cardium, Hiatella, Iso-cardia, Arca, Pectunculus, Nucula, Unio.

C. Ambigua on crinaces: 'The valves unequal, irregular: the linge with one thick tooth, or toothless. The genus Isocardia jvas comprized in this section, but is now removed; there remains in it therefore, no British species.

The second order, C. Unimusculosa comprizes three Sections,

The first, with the Ligament marginal, sublinear, elongated on the edge : comprizing the Genera Modiola, Mytilus, Pinna, Avicula.

Second, Ligament not marginal, contracted into a short space below the beaks, visible, and not forming a tendinous cord under the shell; valves unequal, either in size or shape. It comprizes the Gemera Lima, Pecten, Ostrea, Anomia.

Third, Ligament none, or formed by a tendinous cord supporting the shell : comprizing the Genus Terebratula. 
MULLUSCA. Many of the families of this order are destitute of a shell: the following characters will direct to the Families and Genera in which the native species are contained :

The shell formied in separate pieces, placed transversely across the dorsal surface : Chiton.

The shell of one depressed or conical piece, destitute of convolution. In one or two of the genera, the summit is a little bent, and in another. the internal cavity has a spiral plate: comprizing the Genera Patella, Emarginula, Fissurella, Pileopsis, Calyptræa, Ancylus.

The shell inflated, aperture wide, the length of the shell, no Columella or projecting spire : Bullæa, Bulla.

The shell thin, depressed, the spire short, last whorl large, aperture large, oval: Vitrina.

The shell depressed and earshaped, the spire small, aperture wide oblong, margins separated: Sigaretus, which is distinguished from Natica and Neritina, by its more depressed form, by the width of the aperture, and the want of the umbilical callosity.

The shell spiral somewhat depressed, aperture rounded, the margin disunited, by the projection of the largest whorl witliout a canal: Helix, Zonites, Succinea.

The shell spiral, elevated, aperture entire, the margins disunited by the projection of the largest whorl, no canal: Bulinus, Zua, Pupa, Vertigo, Balea, Carychium.

The shell spiral, elevated, slender, aperture irregular, with the borders united, the lowest whorl not the largest: Clausilia. The other forms of spiral shells, without a canal, will be found in the Genera Cyclostoma, Limneus, Nerita, Natica, Ianthina, Tornatella, Marginella, Voluta, Terebellum, Turbo, Scalaria, 'Trochus, Cingula, Phasianella, Turritella. With the spire very much depressed, Planorbis, Skenea.

Spiral shells, with a canal leading from the aperture : Cerithium, Pleu. rotoma, Fusus, Triton, Purpura, Buccinum, Terebra.

Spiral shells, with a canal and an expansion into a wing of the onter border of the aperture: Rostellaria.

The shell oval, spire scarcely visible, aperture longitudinal, narrow, toothed on both sides, the extremities effuse : Cypræa.

CEPHALOPODA, or CUTTLEFISH TRIBE. Some of the families of this order have no shell; other's have it only internal. In the family of Orthocerata, the shell is straight, or nearly so, with internal chambers, perforated by a tube: Orthocera; easily to be distinguished from Vermetus, and Serpulaceæ, by the internal divisions. As is also the genus Spirula which in outward form approaches to the shape of Spirorbis, but in which the volutions do not touch each other.

The characters of the separate Genera will be found in the body of the work. 


\section{CORNISH FAUNA.}

$-\cdots+6$

The species of which there are Specimens in ths Mruseum are marlied *

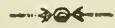

CORNISH SHELLS.

CLASS I.

THE NINTH CLASS OF LAMARK'S AVERTEBRATE ANIMALS.

The third Order of this Class, and first which possesses a Shell, is that of the

\section{SEDENTARY ANNULATA.}

They are formed of tubes either membranous or horny, encrusted outwardly with grains of sand and fragments of shells; or solid, calcareous and homogenous.

To distinguish these from various animals which in the state of Larva construct a case for their temporary protection, it is to be observed that the latter inhabit fresh water only, the former only the sea; and that the contained animal is without eyes, soft, lengthened, wormlike, with segments or transverse wrinkles, mouth nearly terninal, and without articulated feet. It never entirely quits the shell.

\section{MALDANIA.}

DENT A L I UM.

GENERIC CHARACTER: Tube testaccous, nearly regular, slightly curved, gradually diminishimer from one end to the other; open at both ends.

* D. ENTALIS. 'Turton's Linneus. Pennant's British Zoology, vol. 4. pl. 90. Liorlase's Natural Listory of Cornwall, pl. 28, lig. 5. Montagu's 'Tesiacea Britannica, vol. 2, p. 494. Stewart's Elements of Nitural History, vol. 2, p. 421 . Greater Tooth Shell. The dead shell is not unfrequently found on many of our shores, about low water 
mark. I have also obtained it attached to the beard of the greater Pinna, from the depth of above 40 fathouns; but I have not ohtained the animal.

D.DENTALIS. Turt. Lin. D. Striatum. Mont. Test. Brit. vol. 2, p. 495. Striated Tooth Shell. Rare, found by, Montagu at Falmouth; and by myself attached to the Byssus of a Pinna.

D. GADUS. Mont. Test. Brit., vol. 2, p. 496, pl. 14, fig. 7. Montagu says it occurs at a distance from land, attached to the sounding lead of ships in the Channel. On this account I have ventured to class it with Cornish Shells.

It has been supposed that the habit of this genus is to remain fixed in the sand or ooze, and there to protrude their organs for the purpose of laying hold on whatever food may chance to come near; retreating into the shell on the approach of danger, after the manner of the Terebella and Serpulæ. But the observations of Mr. Lansdowne Guilding on a species which be examined in the West Indies, tend to overturn this opinion, and to displace the animal from its situation in the present classification. Placed in a vessel of water, observes this Gentleman, it drew itself along on its side; but this may have been owing to the shallow layer of sand in which it endearoured to bury itself in the soup plate which contained it, where it might not have been able to assume its proper attitude. The creature moves tolerably quick, by sudden interrupted steps. When disturbed it retreats quickly into its shell, which has no operculum, as the Serpulida. After a time the cloak is protruded, the tentacula set in motion, and the vermiform active foot partially thrust out to explore its path. When it wishes to proceed apace, the foot with its petal-shaped alæ closed round the stem, is protruded to its full length; the alæ are then suddenly expanded, and the base of the foot being forcibly contracted, the shell is brought forward, while those expansions laid open in the sand, prevent the apex of the foot from losing its advanced position. Of the place of the Dentalium in the natural system, continues Mr. Guilding, I will not renture to speak at this moment, though perhaps we shall not do wrong in the present state of our knowledgo of the Mollusca, in placing it near the great family, or I should rather say, great tribe of Linnean Patellæ. In its anal opening it resembles the genus Fissurella, while the apicial figure represents the posterior marginal rima of Emarginula. Trans. Lin. Soc. vol. 17, p. 31.

\section{A MPHITRITEA.}

The tube membranous or horny, more or less studded with sand or fragments of Shells. 
SABELLARIA.

GENERIC CHARACTER: Tubes numerous, composed of sand and fragments of shells, united into a common mass by means of a glatinous substance excreted by the animal; the orifices separate to each individual, cupshaped.

* S. Alveolata. Sabella A. Turt. Lin. Pen. Brit. Zo., vol. 4, pl. 92, fig. 162, the figure from an injured specimen. Stew. Elem. Nat. Hist., vol. 2, p. 423. Sabellaria A. Quarterly Journal of Science, vol. 14, pl. 3, fig. 4. Mont. Test. Brit., vol. 2, p. 540. Clustered Sand Tube. Common, and in favourable situations increasing so as to cover a large extent of rock; over which it is impossible to walk without crushing multitudes of these frail habitations. The situation chosen may not at first sight appear the best, for a creature which requires a considerable quantity of sand, before it can be provided with an Labitation, which is placed on the bare rock, at the distance of many feet, or even yards, from the materials. But a bed of sand, though affording materials, would prove a bad foundation for the structure. Trusting therefore to the waves for what they may bring within reach, the building is placed on the elevated surface, and the nost successful season of erection is in stormy weather. In the first stage of existence, and when only a single tube is produced, the appearance of this tube is much like that of Vermilia Triquetra, except in the nature of the materials employed. The orifices of the subsequent formations are more rounded and turned up.

Reasons Lave been given why animals of this and the following genus should be excluded from a work which treats only of shells and their molluscous inhabitants; since these resemble the latter in no respect, and the former only remotely. But faint as is the likeness, it is not altogether visionary, and as it tends to show the links through which the affinities of nature are continued, it deserves our attention. The Arenicolæ, as Cuvier terms them, are not the only creatures in which there is no adbesire attachment between the case and its inhabitant. But the process of construction of these slightly organized habitations is not exceedingly remote from that of the most complete and beautiful of testaceous structures. In the latter, for the purpose of growth, the mantle is applied to the surface of the structure, even beyond tho portion to which it actually adheres; and the exudation of carbonate of lime with animal matter, is plastered on it. But in the case of the present family, the process is so far different, that animal gluten alono is poured out; and this being fastioned into 
a tube by the action of the animal, the arms or tendrils are employed in laying hold of the particles of sand and applying them to the yet adhesive surface.

\section{TEREBELLA.}

GENERIC CHARACTER: Tube lengthened, cylindrical, slender and pointed at the base; membranous, with grains of sand and fragments of shells adbering round it; open only at the top.

* T. CHRYSODON. Sabella C. Mont. Test. Brit., vol. 2, p. 546. Common in firm sand, near low water mark; in some places thickly studding the ground.

* T. CONCHILEGA. Sabella C. Pen. Brit. Zo., vol. 4, pl. 26, lower figure. Stew. Elem., vol. 2, p. 423. Mont. Test. Brit., vol. 2, p. 547. On dead shells from deep water.

* T. LUMBricAlis. Sabella L. Stew. Elem., vol. 2, p. 423. Mont. Test. Brit., rol. 2, p. 549. Common, on shells, from deep water.

T. CIRRATA. Sabella C. Mont. Test. Brit., vol. 2, p. 550. This is the largest, stoutest, finest, but most brittle, of the British species. It lives in deep water, and is probably less rare than it seems to be.

The above form the whole of the species comprized in the kindred Genera Sabellaria and Terebella that I can venture to include in the list of Cornish Shells. But although differently allied, Siphunculus Strombus (Fleming's British Animals, p. 491) must also be enumerated among creatures which construct their habitation of agglutinated sand. This it does by straitening the orifice of the shell of Rostellaria Pes Pelecani; and forming it into an elevated nest, within which its takes up its permanent abode.

\section{AMPHITKITE.}

GENERIC CHARACTER. Tube lengthened, cylindrical, the hinder extremity tapering, membranous or leathery; the outer surface generally naked.

A. PENICILLUS. Sabella P. Mont. Test. Brit., vol. 2, p. 541. Cylindrical, size of a crow quill, 3 inches long, tapering and a little flexuous at the base, where alone it is fixed; the upper portion free, and floating. The surface smooth, as if covered with a muddy coating, nearly black, and finely marked with circular lines. On the Pinna Ingens, and sometimes on Sertularia Abietina growing on it: from the depth of 40 or 50 fathoms.

SERPULAEA.

Tube solid, calcareous; the branchiæ covered with an operculum. 


\section{SPIRORBIS.}

GENERIC CIIARACTER: Tube testaceous, twisted into a round flattened spire; lower surface flat, and fixed to another body. Operculum pedunculated, flat at the top, situate between the branchiæ.

* SP. NAUTILOIDES. Serpula Spirorbis. Turt. Lin. Pen. Brit. Zo., vol. 4, pl. 91, fig. 155. Stew. Elem., vol. 2, p. 422. Mont. Test. Brit., vol. 2, p. 498. Common on stones, shells and other substances.

SP. SPIRILLUM. Serpula Sp. Turt. Lin. Stew. Elem., vol. 2, p. 421. Mont. 'Test. Brit., vol. 2, p. 499.

Montagu says, this species bas much the habit of the preceding, but is distinguished from it by its glossy appearance, being more cylindric, and not spreading at the base. Common on shells, stones and other substances.

* SP. GRANULATA. Serpula G. and Sulcata. Turt. Lin. Mont. Test. Brit., vol. 2, p. 500. Common on rocks and stones.

* SP. CARINATA. Serpula C. Mont. Test. Brit., vol. 2, p. 502. It is distinguished from Sp. Nautiloides by the angulated shape of the outer whirl, which is formed like that of Vermilia Triquetra, but regularly spiral. Not uncommon on shells.

* SP. CORRUGATA. Serpula C. Mont. Test. Brit., vol. 2, p. 502. Not uncommon.

* SP. MINUTA. Serpula M. Mont, Test. Brit, vol. 2, p. 505.

Montagu observes, this very minute species is also an heteroclitical shell, and not easily distinguished from S. Heterostropha, except hy its inferior size, and habits; this affects only the Corallina officinalis, frequently in abundance, both on stalks and branches.

SP. LUCIDA. Serpula Reflexa and S. Vitrea. Turt. Lin. S. L. Mont. Test. Brit., vol. 2, p. 507 .

Montagu says, it is peculiar to some species of Sertularia, especially S. Abietina and S. Argentea; and on them not uncomunon.

\section{SERPULA.}

GENERIC CHARACTER: Tube testaceous, creeping, tapering, irregularly twisted, sometimes sligbtly keeled; fixed to another body.

- S. Vermicularis. S. Intricata. Turt. Lin. Pen. Brit. Zo., vol. 4, pl. 91, fig. misplaced, 158. Stew. Elem., rol. 2, p. 422. Mont. Test. Brit., vol. 2, p. 509. Common.

* S. TUBUlariA. Mont. Test. Brit, vol. 2, p. 513 . The most beautiful, and commonly the largest, of the British Serpulax. It comes from dcep water, and is scarcely common. 


\section{VERMILIA.}

GENERIC CHARACTER: Tube testaceous, tapering, irregularly twisted, fixed to some other body; margin of the aperture toothed.

* V. TRIQUETRA. Serpula Contortuplicata. Turt. Lin. Pen. Brit. Zo., vol. 4, pl. 91. fig. misplaced, 157. Stew. Elem., vol. 2, p. 422. S. T. Mont. Test. Brit., vol. 2, p. 511. Pennant's figures, in addition to the error of the references, are from imperfect specimens. Common.

The principal authority for the specific distinctions of the British species of this family, is Montagu, who has closely studied them. It seems proper to remark, however, that the direction in which the spire may turn, to the right or left, may not prove so unchangeable a mark as to warrant its forming a specific distinction.

\section{CLASS II.}

\section{CIRRHIPEDA.}

The shell with many valves, sessile or on a stalk; the valves or plates unequal, covered inwardly by the mantle. The animal is soft, without head or eyes, testaceous, fixed. Body not articulated, having a mantle, with cirrous, many jointed, tentacular arms. Number of the arms various, unequal, in two rows, each composed of two setaceous, jointed, fringed cirri, supported on a common footstalk. It is the class Cirrhopoda of Cuvier, and genus Lepas of Linneus.

\section{SESSILE CIRRHIPEDA.}

The shell seated on some solid body, irregularly conical, with imperfect divisions, truncated at the top, where is the opening, closed with four interior valves.

\section{TUBICINELLA.}

GENERIC CHARACTER: Tube cylindrical, with six elongated valves jointed together side by side, striated longitudinally, surrounded by concentric rings; open at the sumnit, and closed with a membrane at the base. Operculum witb four obtuse valves.

* T. Clarata. Balanus C. Pen. Brit. Zo., vol. 4, pl. 37, A. 5. Mont. Test. Brit, vol. 1, p. 10. On rocks in Mount's Bay.

\section{BALANUS.}

GENERIC CHARACTER: Shell sessile, fixed, conical, the top truncated, orifice irregular; the base formed by a 
testaceous plate. The opening on the top closed by four moveable valves, inserted near the base of the inside of the shell.

- B. COMMUNIS. Lepas Balanus. Turt. Lin. L. Cornubiensis. Pen. Brit. Zo., vol. 4, pl. 37, fig. 6. B. C. Mont. Test. Brit., vol. 1, p. 66. Stew. Elem., vol. p. 363. Acorn shell. Common on rocks; clustering.

-B. BAlanoides. Lepas B. Turt. Lin. Pen. Brit, Zo., vol. 4, pl. 37, fig. 5. Stew. Eleın., vol. 2, p. 314, B. B. Mont. Test. Brit., rol. 1, p. 7. Covering rocks, in multitudes.

* B. PUNCTA TUS. Mont. Test. Brit., vol. 1, p. 8, and pl. 1, fig. 5. 'This has generally been confounded with the preceding: a circumstance not surprizing, from the little attention hitherto paid to these animals, and the difference of their form from variety of position, clustering and age.

B. TINTINNABULUM. Mont. Test. Brit, vol. 1, p. 10.

Montagu describes this shell from specimens attached to the bottoms of ships from warm climates; but doubts of its being a native of our seas. I have found numerous speciniens, answering to his description in all but size, attached to the surface of the Nidus of Buccinum Undatum, thrown on shore on the beach, and consequently from no great distance in the ocean. A comparison of these specimens, scarcely a line in diameter, with the foreign shells, which are among the largest of the genus, may lead to a suspicion that they are not certainly identical; in which case the Cornish will be a new species; but this must be left for further investigation. The colour of this shell is pure white; of the inner valves purple.

ACASTA.

GENERIC CHARACTER: The shell sessile, oval, sub. conic; formed of separable pieces, forning six unequal plates; the bottom a convex plate externally. Cover with four valves.

A. MONTAGUI. Crouch's Introduction to Lamark's Conchology, pl. 1, fig. 15. This species does not fix on solid bodies, but lires embedded in sponge. It is obtained fiom deep water, and is scarcely common.

\section{CREUSIA.}

GENERIC CHARACTER: The shell sessile, fixed, orbicular, with four plates, which are unequal, united by distinct sutures. Cover internal, with four valves.

* C. STRIA'TA. Lepas Intertexta. 'Turt. Lin. L. Striata. Pen. Brit. Zo., vol. 4, pl. 38, fig. 7. Balanus S. Mont. Test. Brit., rol. 1 p. 12. L. S. Stew. Elem., vol. 2, p. 364. Common on shells, rocks, and the stalks of seaweeds where not often uncovered by the tide: clustering, but not so as to influence the regularity of growth. 
PYRGOMA.

GENERIC CHARACTER: Shell sessile, of one piace s!bglobular, bulging, convex above, the top perforated with a small orifice, which inclines to oval. Cover with four valves, scarcely apparent.

* P. ANGLICUM. Magazine of Natural History, O. S., vol. $1, \mathrm{p} .475$. It is rare that a full grown and complete Caryopbyllia Smithii (a species of coral) is brought from moderately deep water, without having a few specimens seated on its diverging plates; and I have rarely seen it under other circanstances.

\section{PEDUNCULATED CIRRHIPEDA.}

The shell supported by a tubular stalk, the base attached to some foreign body.

\section{ANATIFERA.}

GENERIC CHARACTER: The shell compressed at the sides, with 5 plates, which are contiguous and unequal; the lower side plates largest. This genus is also termed Anatifa, and Anatifer.

* A. LEVIS. Lepas Anatifera. Turt. Lin. Pen. Brit. Zo., vol. 4, pl. 38. fig.9. Stew. Elem., vol. 2, p. 364. Mont. Test. Brit., vol. 1, p. 15. A. L. Crouch's In., pl. 1, fig. 18. Barnacle.

This which is termed the Duck or clustering Barnacle, is the largest of the British species, sometimes measuring from the base of the shell to the point $2 \frac{1}{2}$ inches; and to distinguish it from the next, with which it is commonly confounded, it should be remarked as being more robust, and larger, while the stalk is comparatirely shorter. The union of the larger plates is eqnal, and their margin rises forward in a rounded shape, again descending with a sweep; while in the next species the hinge is formed by the overlapping of one of the plates; and their margin without rising passes forward, obliquely descending to the opening. In the latter also, the anterior plate leaves a larger membranous space at its produced portion, where it passes between the dorsal plate and the larger lateral. The dorsal plate of $\mathbf{A}$. Levis is more ridged and elevated: the edge amounting to a keel at its bend. The graining on the surface of the plates, the absence of which in the present species has been deemed of sufficient importance to afford a trivial name, cannot be depended on for distinction. This species is found, sometimes in immense numbers, attached to wood that has been floating on the ocean; but instances of their occurrence are not nearly so frequent, as of the next species. Each kind is found occupying its own separate wreck, and may readily be distinguished, the present species by the clustering of its young on the stalk or shell of the parent, while on 
the other this is never observed. The young thus adhering are nerer of the full size of the parent: a circumstance not casily accounted for; as it seems impossible that they should at any time after their first stages of growth, be able to loosen their hold and assume a new station.

The researches of Mr. Thompson have made the history of this class of animals important, by showing their close affinity with Crabs and Lobsters.

* A. ANSERIfERA. Lepas A. 'Turt. Lin. Mont. Test. Brit., vol. 1, p. 16. Stew. Elem., vol. 2, p. 364. Common Barnacle. Common on floating wood that has been long at sea. Its distinctions from the A. Levis have been already pointed out. The stalk, which is from a foot to 18 inches in length, is capable of voluntary motion, including contraction and extension; and a point of support for lateral bending is afforded by compressing a portion of fluid into the requisite limited space.

* A. FASCICULARIS. Lepas F. Mont. Test. Brit, vol. 2 , p. 557. In no volume to which I have access do I find a satisfactory description of this species; it may therefore properly find a place here. Length of the shell, 7 tenths of an inch, depth $5 \frac{1}{2}$ tenths ; the thickness or inflation considerable, the cross segment forming an oval posteriorly; texture of the plates thin as tissue paper, and easily broken. The dorsal plate is remarkably arched, wide, and terminating circularly above the stalk. The orifice gaping. Anterior lateral plate small, slender, jagged at its point; the larger plate with an everted hinder margin. Colour whitish, with tints of blue, the soft parts appearing through the texture. The stalk short, small, fixed in a tumid bed of soft membranous substance; and the animals project at right angles to the substance on which they are fixed; adhering in clusters, but each standing out in as opposite a direction as possible from those with which it is associated.

This is a rare species, since it was but barely known to the industrious researches of Montagu. I have met with it attached to the stalk of sea weeds; and once in considerable quantity, thrown on shore in a storn. It is a stranger circumstance that I possess some specimens, intermingled with the equally rare species, A. Sulcata, and both attached to a feather of the wing of a gull.

A. SULCATd. Lepas S. Mont. 'Test. Brit., vol. 1, p. 17, pl. 1, fig. 6. Length of the shell 7 tentls of an inch, depth $4 \frac{1}{3}$ tenths. The larger plates are moderately inllated behind, overlapping at the hinge below; the anterior plates small; dorsal plate not ruming to the point. The side plates are thickly covered with raised lines procecding 
from the inferior point of the junction of these parts, and directed obliquely upward to the erige; where they are opposite to similar lines on the smaller plate, which converge on a part of the superior margin a little distant from the point: from which latter portion similar lines pass obliquely upward and backward to the same space. The dorsal plate has a distinct smooth ridge or keel; but possesses longitudinal lines passing from behind forward to the edge. Colour a leaden blue, the stalk short, almost sessile.

Montagu once found this species, in an immature state, attached to the Gorgonia Flabellum: a species of coral not yet beyond a doubt, as a native of the British Seas. Some specimens were presented to me by a young Lady, from the coast of Ireland; and on the following day I was so fortunate as to find a collection of them, attached in clumps on both sides of a piece of the bark of a tree. Comparing these with Montagu's description and figure, I find the terminal side plate less sharp, and the characteristic raised lines more numerous; for in Montagu's specimens there were no more than 15, which he terms strong ribs; while in the larger individuals from which my description was drawn, there were 28 in one, and 29 in another. On the lesser side plate I counted 17, instead of seven or eight as noticed by Montagu. All of them were of an equal marking, so as to give the specimens an elegant appearance: the plates closely.joined, without an appearance of membrane; and the lines on both plates continuous, instead of forming an angle, as in Montagu's figure. The Irish specimens in this respect approach more nearly to the engraving; their breadth being greater than the Cornish, in comparison with their length: the plates also of a firmer texture, with a few undulations crossing the raised lines; those on the anterior plates also standing at an angle with those behind. But these again differ from Montagu's specimens in having 38 lines on the hinder plate, and 20 on the anterior, with none on the dorsal plate. The overlapping of the right plate over the left, is common to the whole of these specimens and Montagu's fignre. Shortly after the discovery of these specimens, I obtained a piece of cork, such as is employed by fishermen for their nets; and on one side of it were found several small specimens of this Barnacle, scattered singly over its surface. Including the footstalk which indeed is too short to enter into the measurement, their length did not exceed the tenth of an inch; and their structure was more rough and unsightly, the raised lines less numerous and regular, than in my former and larger specimens. About the same time also, Mr. Jackson, 
of East Looe, to whom our museum is indebted for much valuable assistance, presented to me the feather already referred to when speaking of the last species:-on which, along the stem of the vane, were several specimens of this species, standing in clumps, and of about their full growth. It is clear that they must have seized on this feather, as well as on the piece of cork when floating on the surface; and that in their first existence they are singly dotted over the surface. Their clustering afterwards is in the way of pullulation; and though closely set in the bottom, their subsequent growth, is in every imaginable angle of direction.

\section{POLLICIPES.}

GENERIC CHARACTER: The shell compressed at the sides, many valved, the plates ratber contiguous, unequal; in number 13, or more; the lower side valves smallest.

* P. SCALPELLUM. Lepas S. Turt. Lin. Mont. Test. Brit., vol. 1, p. 18, pl. 1, 6g. 3. Stew. Elem., vol. 2, p. 365 .

This species has been described as scarce; but I have found it common, if not abundant. It is found on the branches of Gorgonia Verrucosa, and Dynamena Filicula, two species of Corals; and somewhat less frequently, but of greater size, on the stone to which they are attached; but in every case, it stands erect, and singly, without clustering.

\section{CLASS III.}

\section{CONCHIFERA.}

The sliell always bivalve, wholly or partly covering the animal; sometimes free, sometimes fixed; the valves mostly joined at the margin by a hinge or ligament. The shell is sometimes enlarged by testaceous or accessary pieces, not belonging to the valves.

This class is divided into two orders: Conchitera bimusculosa, and C. Unimusculosa.

\section{ORDER I.}

\section{CONCHIFERA BIMUSCULOSA :}

So named from having, in the interior, two separate and lateral muscular impressions. It is divided into four sections: C. Crassipeda; C. Tenuipeda; C. Lamellipeda; and C. Ambigua, or the Chamacea. 
SECTION I.

\section{CONCHIFERA CRASSIPEDA:}

The foot of the animal thick, the shell gaping considerably. This section contains four families: Tubicolaria, Pholaderia, Solenacea, and Myaria.

Inhabiting a tube.

\section{TUBICOLARIA.}

\section{TEREDO.}

GENERIC CHARACTER: Tube testaceous, cylindrical, flexuous, open at both ends, not belonging to the shell, and covering the animal. Shell bivalre, placed posteriorly, on the outside of the tube.

* T. NAVALIS. Lin. Pen. Rrit. Zo., rol. 4, p. 147. Stew. Elem., vol. 2, p. 423. Mont. Test. Brit., vol. 2, p. 527. Fleming's British Animals, p. 454. 'The posterior valves or pallets, Crouch's Intr., pl. 2, fig. 1.0, b, the jaw 10 a. Auger Worm.

This animal enters wood that has been penetrated hy Sea Water, and soon enlarges its habitation; devouring tortuously in the direction of the fibres, and filling its intestines with the saw dust, to a state of great distension. It penetrates to the length of about a foot, in a chamber something less than an inch in diameter: and is capable of retracting itself, or turning in an inclined direction, to avoid any formidable obstacle. At first these animals do not eat into each others chambers; and when this has happened, they retreat and take a new direction. But when their numbers, and the complexity of their habitations have increased, the substance of the wood may be found pierced in all directions, so as at last to fall asunder; and like the fabled hero of antiquity, the life of the animal depending on the existence of the log, the whole perish together.

Their mode of increase is uncertain; but at an early period of their lives they must possess a free existence, for they enter wood that has never been deeply immersed; and that, contrary to former opinion, they are permanent inhabitants of our sea, appears from the fact, that they have been found in wood belonging to vessels, sailing from our own ports, that have sunk on our coast; and the timbers of which have been afterwards recovered.

* T. MALleOLUS. Flem. Brit. An., p. 454.

This species is smaller than t'de former; it is probably more rare, and in my observation, the tube is more slight and thin. As however, my remarks are derived from some that had not penetrated deeply, I do not feel confident in the greneral want of solidity of the tube; for in the T. Navalis, even when of considerable size, the tube is often found as 
thin as a filn!, more especially towards the anterior part. Yet even in its very immature state, the tube of this species has near the tail, some distinct testaceous chambers : showing the faet that the body makes some progress beyond simple growth: a circumstance less clearly established in the common Auger Worm. The chief, or at least, the most clear and easy distinction between this species and T. $\mathrm{N}$ avalis will be found in the structure of their jaws : the cutting portion of which, or triangular projection, in the latter species being bent obliquely downward, but not nearly so much so as in T. Malleolus, In T. Navalis, fine, slight, closely placed lines radiate backward from this point to where the upper portion of them joins a series of similar strix that pass upward in an arched manner, each line turning off backward into a nat space which ends abruptly. The jaws of T. Malleolus are more glossy, and the divergent lines of the triangular portion are less numerous and more distinctly separate; the striæ being more prominent, with wider spaces between them. The perpendicular lines also, which run at right angles to the former, are also more distinct, though examined in a much smaller specimen; and turn off backward in separate, but not as in the former, in wide arches.

T. NANA. Flem. Brit. An., p. 455; whose sole authority is Turton. The shell is four tenths of an inch in diameter, in both directions, though too irregular to be termed round; very deep in the hollow, almost globular. A slender, but very distinct rib passes round the concavity, from the slight but firm oblique tooth at the portion that is incurved, to the opposite margin. This rare species was found in a piece of oak, thrown on shore at Gorran: communicated by Mr. Peach.

\section{PHOLADARIA.}

Shell without a tubular sheath, gaping anteriorly; ligament external, and with accessory pieces of shell not belonging to the valves.

\section{PHOLAS.}

GENERIC CHARACTER: Shell bivalve, equalralved, transverse, gaping at both sides, having accessary pieces affixed above or below the hinge. The inferior or posterior margin of the valres reflected ontward.

P. DAC'TYLUS. 'Turt. Lin. Borlase's Nat. Hist. Corn., pl. 28, fig. 31. Pen. Brit. 'Zo., vol. 4, pl. 39, fig. 10 . Mont. Test. Brit., vol. 1, p. 20. Flcm. Brit. An., p. 457. This shell is a borer, commonly of the hard rock, in which it lives at ense, and by which it is protected from injury. I have only seen it as taken from slate rock on the west side of Pridmouth Cove, not far west of Fowey. 
* P. LAMELLATA. Flem. Brit. An., p. 456. Numerous in a reddish sandstone, from deep water, drawn up by a fisherman's hook. Mr. Bellamy says it is not uncommon at Plymouth.

\section{GASTROCHENA.}

GENERIC CHARACTER: The shell bivalve, the valves equal, rather wedge shaped, gaping very much; the anterior aperture large, oval, oblique; scarcely any aperture posteriorly. Hinge, linear, margina!, without teeth.

G. HIANS. Mya Dubia. Turt. Lin. Pen. Brit. Zo., vol. 4, pl. 44, fig. 19. M. Pholadia. Mont. Test. Brit., vol. 1, p. 28. G. H. Flem. Brit. An., p. 458. Scarce. I have seen it taken alive from the cavity of a stone from deep water.

\section{SOLENACEA.}

The Shell transversely elongated, gaping only at the lateral extremities. Ligament external. Accessary pieces none.

\section{SOLEN.}

GENERIC CHARACTER: Shell bivalve, the valves equal, transversely elongated, gaping at both ends beaks small, not projecting. Ligament external, near the hinge.

* S. SILIQUA. Turt. Lin. Pen. Brit. Zo., vol. 4, pl. 45, fig. 20. Mont. Test. Brit., vol. 1, p. 46. Stew. Elem., vol. 2, p. 369. Flem. Brit. An., p. 459. Razor Shell. From the specimens and fragments found lying on the shore, this animal seems not uncommon; but several circumstances render it not easy to be found in its living state.

S. PELLUCIDUS. Turt. Lin. Pen. Brit. Zo., vol. 4, pl. 46, fig. 23. Mont. Test. Brit., vol. 1, p. 49. Flem. Brit. An., p. 459. Rare; and the more so, that it must be taken alive, to be obtained perfect. Montagu obtained it in Cornwall, and I possess a specimen from Ireland.

S. DECLIVIS. Flem. Brit. An., p. 460. Dr. Fleming, who is the only authority for this shell, reports it as occuring in the Scilly Islands.

S. ANTIQUATUS. S. Cultellus. Pen. Brit. Zo., vol. 4, pl. 46, fig. 25, but not of Linneus; S. A. Mont. Test. Brit., vol. 1, p. 52. Flem. Brit. An., p. 52. Rare. Montagu obtained a specimen near Looe; and it has been found at Gorran by Mr. Peach.

\section{$M Y A R I A$.}

Ligament internal; one large spoonshaped tooth, in one or both valves, to the cavity of which the ligament is attached. Shell gaping at one or both of its sides.

MYA.

GENERIC CHARACTER: Shell bivalve, transverse, gaping at both ends; with one large cardinal tooth in the 
left valve, broadly compressed, rather rounded, and projecting almost vertically; a cardinal pit in the other valve. Ligament internal, inserted in the prominent tooth and the corresponding pit.

M. TRUNCATA. 'Turt. Lin. Pen. Brit.Zo., vol. 4, pl. 41, fig. 14. Stew. Elem., vol. 2. p. 336. Mont. Test. Brit., vol. 1, p. 32, Flem. Brit. An. p. 162. Rare.

\section{ANATINA.}

GENERIC CHARACTER: Shell transverse, with nearly equal valves, gaping at one or both sides; one naked, broad, spoonshaped, cardinal tooth, projecting internally, in each valve, and receiving the ligament. In many species a lamina or falcated rib runs obliquely below the cardinal teeth.

A. MYALIS. Mya Pubescens. Mont. Test. Brit., vol. 1, p. 40. Amphisdesma P. Flem. Brit. An., p. 431. Anatina M. Crouch's Introd., pl. 4, fig. 1.

Montagu says, "this species is not uncommon, of small size, taken up with sand from Falmouth harbour-one we received from Plymouth, taken by dredging, was 2 inches broad, and $1 \frac{1}{4}$ long." It is otherwise rare; but $I$ obtained it at Falmouth, above $2 \frac{1}{2}$ inches broad.

A. DECLIVIS. Marked for me at the British Museum, but which I am not able with confidence to refer to any of the usually received synonyms of this shell : considered, as it usually is, as the young state of the last species. Pennant, Montagu and Fleming, are entirely at variance on this subject; and until more information is obtained, it is best to report it simply, as not of common occurrence within the sphere of my observation.

\section{SECTION II.}

The foot small, compressed; Lobes of the mantle scarcely or not at all united in front. Lateral gaping of the shell generally inconsiderable.

\section{MACTRACEA.}

The shell with equal valves, generally gaping at the lateral extremities. Ligament internal, with or without an external ligament.

\section{LUTRARIA.}

GENERIC CHARACTER: The shell with unequal sides, transversely oblong or rounded, lateral extremities gaping; hinge with one tooth folded in two; or two teeth, one of which is simple, with an adjoining, deltoid, oblique pit, projecting inwards; no lateral teeth. Ligament internal, affixed in the pits.

* L. VULGaris. Mactra Lutraria. Turt. Lin. Pen. Brit. Zo., vol. 4, pl. 52, fig. 44. Stew. Elem., vol. 2, 
p. 37\%. Mont. Test. Brit., vol. 1, p. 99. L. V. Flem, Brit. An., p. 464. The separate valves are found thinly scattered along all our coasts.

L. HIANS. Mactra H. Mont. Test. Brit., vol. 1, p. 101. My a oblonga, Turt. Lin. L. H. Flem. Brit. An., p. 465. Rare or local. Montagu found it not uncommon in the river between Truro and Falmouth.

\section{MACTRA.}

GENERIC CHARACTER: Shell transverse, the sides unequal; the form subtriangular, gaping very little at the sides; beaks prominent. One compressed, grooved, cardinal tooth in each valve, with an adjoining pit projecting inwards; two compressed, entering, lateral teeth, near the hinge. Ligament internal, inserted in the cardinal pits.

* M. SOLIDA. Turt. Lin. Pen. Brit. Zo., vol.4, pl. 50, fig. 43. Stew. Elem., vol. 2, p. 377. Mont. Test. Brit., vol. 1, p. 92. Flem. Brit. An., p. 26. Abundant along our southern coast.

On the beach at Helford, near Falmouth, I obtained a complete'shell and two separate valves of, what must be considered, a separate species or a variety of the above, as future research shall deternine. It is of the ordinary size and appearance of the milk white specimens of M. Solida; but from each umbo proceeds to the posterior margin a deep channel, which forms an indentation at their place of meeting. I had no opportunity of examining the animal.

* M. TRUNCATA. M. Subtruncata. Mont. Test. Brit., vol. 1, p. 93. M. Stultorum. Pen. Brit. Zo., vol. 4, pl. 52, fig. 42. Stew. Elem., vol. 2, p. 377. M. T. Flem. Brit. An., p. 42\%. I have found it larger than the last named species; frequenting similar situations, but less abundant.

M. GLAUCA. Mont. Test. Brit., vol. 2, p. 571. Flem. Brit. An., p. 428. Found by Miss Pocock on Halesands, under Lelant.

* M. STULTORUM. Turt Lin. Tellina Radiata (in Montagu's opinion) Pen. Brit. Zo., vol. 4, pl. 49, fig. 30. M. S. Mont. Test: Brit., vol. 1, p. 94. Stew. Elm. vol. 2, p. 376. Flem. Brit. An., p. 42\%. Not common on the eastern shores; but occurring on the north and south coasts, and at Pentuan in abundance.

M. DEALBATA. Mont. Test. Brit., vol. 1, p.95. Flem. Brit. An., p. 428. Scarce.

M. MrNUTISSIMA. Goodallia M. Flem. Brit. An., p. 429 .

\section{AMPHIDESMA.}

GENERIC CHARACTEK: The shell transverse, sides unequal, rounded, sometines gaping a little; hinge with 
one or two teeth, and a narrow pit for the internal ligament. Ligament double; one external, short, the other internal, fixed in the cardinal pits.

* A. COMPRESSUM. Mactra Listeri. Turt. Lin. Stew. Elem., vol. 2, p. 377. Venus Borealis. Pen. Brit. Zo., vol. 4, p. 96. Mactra C. Mont. Test. Brit., vol. 1, p. 96. A. C. Flem. Brit. An., p. 432. On heaps of sand on the banks of Looe river, and probably in other similar situations; but scarcely abundant.

* A. PRAETENUE. Mya P. Mont. Test. Brit., vol. 1, p. 41. A. P. Flem. Brit. An., p. 432. "It is not uncommonly dredged from Falmouth harbour, but mostly single valves." Montagu. I obtained a specimen with the valves united.

A. DISTORTUM. Mya D. Mont. Test. Brit., vol. 1, p. 42. pl. 1, fig. 1. A. D. Flem. Brit. An., p. 432. "We first noticed this species at Falmouth, amongst the sand dredged from the harbour for manure, and have since found it lodged in hard limestone at Plymouth, into which it had bored like the Pholas; probably the occasion of its distorted growth." Montagu. I have found it not uncom. mon in stones from deep water; and ascribe the distorted growth to its occupying holes not made by itself, and which in time become too straight for it. Animals which form their own habitations in the substance of the stone, are commonly found to enlarge them according to their grosth ; and maintain the most delicate structure of their shells without injury.

A, CONVEXUM. Turt. Lin. Flem. Br. An., p. 431. Obtained from Mr. Peach at Gorran.

Other species arranged by Fleming in this genus, will be found in the genus Anatina.

CORBULEA.

Valves of the shell unequal; ligament interior.

CORBULA.

GENERIC CHARACTER: The shell regular, valves unequal, as also the sides; closed or very slightly gaping. One large, conical, curved, ascending tooth in each valve, with a pit beside it; no lateral teeth. Ligament internal, inserted in the pits.

C. NUCLEUS. Mya Inequivalvis. Mont. Test. Brit, vol. 1, p. 38. C. Striata. Flem. Brit. An., p. 425. C. N. Quarterly Journal of Science, vol. 14, pl. 5, Gy. s8.

Montagu says, "this shell is by no means uncommon; but rarely to be obtained alive, or with coenected valies; we have found it on the coasts of Cornwall and Devonshire: and in a living state dredged from Salcomb bay." I have obtained it from Gorran. 
LITHOPHAGA.

Boring shells, witiont accessary pieces or sheath, and more or less gaping at the anterior side. Ligament external. SAXICAVA.

GENERIC CHARACTER: Shell bivalve, transverse, the sides unequal; gaping interiorly at the superior margin; hinge almost witliont teeth.

* S. Rugosa. Mytilus R. Turt. Lin. Pen. Brit. Zo., rol. 4, pl. 63, fig. 72. Mag. Nat. Hist., O. S., vol. 4, p. 358. The boring species of shell-fish found in Britain belong chielly to the genera Teredo, Pholas and Saxicara; for it may be doubted whether any of the other families, though found in similar situations, are able to form for themselres the chambers they inbabit. The Teredines are found only in wood, which when soaked in sea-water they readily devour, so that their intestines are found greatly distended with it. The Pholades prefer the hard rock: either the common slate of onr coast, which when young they readily penetrate, and hollow smoothly ont to the depth of several inches, with a diarneter equal to the comfortable expansion of the shell: or the sandstone found in the sea at no great distance. Limestone is also subject to their depredations, but it seems, less frequently ; and when the chamber is become sulficiently large for thoir full gl ow th, wo further destruction ensues, except from the multiplication of indiriduals. The Saxicava Rugosa, though a much smaller Animal, is far more destructire, from being much more generally destributed, and in greater numbers. It has also of late attracted special attention from having spread its ravages along the whole front of the Breakwater at Plymouth; and thereby excited in the minds of some, very serious apprehensions for the safety of that edifice, Its devastation appears to be confined to substances of which a chief constituent is lime; which it enters when young, and which it is nerer found to penetrate beyond the deptli of about six inches. It can therctore only be when the honcy-amb-work of its operation shall have been broken of by the violence of the waves, that a further extension of its ravages can be apprehended: a circumstance which may be prevented by occasionally throwing along the face of the structure, fragments of mineral substances, as iron or copper; the poison of which would be fatal to the Animals. Their operation is not observed to extend much below the low water mark. The manner in which these burrowing Mollusks effect their operation on the solid rock, has been the subject of controversy, and perhars may differ in the different families. It is certain that the Teredines effect the desfruction of wood by the 
griuding of their singularly forned jaws, The Sasicava Rugosa las its projectile organ or tongue, a rough rasplike structure which may be supposed by repeated application to be capable of wearing down the substance of the rock; but in other horing animals, some of which are naked, and perform the operation on the shells of Bivalves, for the purpose of devouring the Mollusk within, no such structure has hitherto been detected; and the Saxicaya Rugosa itself seems indisposed or incapable to penctrate any other rock beside that of limestone. It is probable therefore, that some digestive application with chemical powers is first made use of, by which the mechanical operation of the tongue is the more easily secured. 'This slerder organ is sometimes found protruded, occasinnally in a tortuous direction, in a passage through the stone, to the length of nearly two inches, with a transverse measurement not exceeding its own breadth : a circumstance which seems to show, that the operation is as much for obtuining food, as for the purpose of enlarging its habitation.

This species of Saxicava preserves its membranous covering while enclosed in its rocky cave; but when, as is sometimes the case, it has become enveloped in a mass of coral, it becomes denuded, and so changed in form as scarcely to be recognized.

\section{VENERIR UPIS.}

GENERIC CHARACTER: The shell transwerse, sides unequal; the posterior side very short, the anterior gaping slightly. Hinge with two teeth in the right valie, and three in the left, sometimes three in each, the teeth small, approximate, parallel, and but little or not at all divergent. Ligament external.

* V. DECUSSATA. Venus Literata. Turt. Lin. Pen. Brit. Zo., vol. 4, pl. 57, fig. 53. V. Decussata. Mont. Test. Brit., vol. 1, p. 124. Stew. Elem., vol. 2, p. 332. Venerupis D. Flem. Brit. An., p. 451. Common in harbours through which a fresh stream flows. I have obtained it from Looe, so near the surface of the ground, that the muscles had fastenet their byssus to it. This and the following are termed hens, to distinguish them from cocks or cockles.

- V. PUllastra. Venus P. Mont. Test. Brit., vol. 1. p. 125. Venerupis P. Flem. Brit. An., p. 451. This is by Sowerby consituted the type of the genus Pullastra. It is common, though by sereral Naturalists strangely overlooked or confounded with less common kinds. It burrows, in rather firm ground, a few inches bescalls the sarface. 
V. VIRGineA. Venus V. Turt. Lin. Pen. Brit. Zo., vol. 4, pl. 55, without a number. Stew. Eln., vol. 2, n. 382. Mont. Test. Brit., vol. I, p. 128. Venerupis V. Flem. Brit. An., p. 452. Not uncommon in St. Austle bay; and dead shells with the valves adhering, abundant in the mud taken up in deepening Falmouth harbour. It is also one of the shells that came from the stream work, now abandoned, at Pentewan.

* V. PERFORANS. Venus P. Mont. Test. Brit., vol. 1, p. 12\%, pl. 3, fig. 6. Flem. Brit. An., p. 451.

Montagu observes, "This species at first sight might readily be confounded with the young of the V. Decussata; but the slender and recurved teeth is a discriminating character, if all others were wanting. It rarely exceeds three eighths of an inch in length, and five eighths in breadth. With respect to shape it is difficult to fix any as a permanent character; it is however most frequently subrhomboidal; sometimes nearly as long as it is broad, generally straight on the front margin, but in some instances deeply sinuous or indented; not very unlike Mr. Pennant's figure of the V. Sinuosa. We found this species in abundance on the shore near Plymouth, burrowed in hard limestone, detached fragments of which were perforated in all directions, and stuck full of them."

From these remarks it would appear that Montagu had never seen this shell, except as imbedded in a substance that modified its character and perhaps stunted its growth. Dr. Fleming describes it as in length about an inch, breadth two inches and half. But a specimen which I have obtained, that had never been embedded in stone, answers more correctly to Montagu's figure and description, than to any other which I have had an opportunity of inspecting. It is not easy to suppose that the figures given in Crouch's Introduction to Lamarck, pl. 5, fig. 5, and the Journal of Science, vol. 14 , pl. 5 , fig. 42 , can apply to the same species.

V. IRUS. Donax Irus. Turt. Lin. Tellina Cornubiensis.

Pen. Brit. Zo., vol. 4. Borlase's Nat. Hist. Corn., pl. 28, fig. 23. D. I. Mont. Test. Brit., vol. 1, p. 108. Venerupis I. Flem. Brit. An., p. 451. Rare. Borlase found it in the west of the County.

* V. SARNIENSIS. Flem. Brit. An., p. 452. Several specimens which I assign to this species, from Falmouth and St. Austle bay.

NYMPH.A CEA.

Two cardinal tecth at most, on the same valve. Shell often sligbuly gaping at the lateral extremities. Ligament ,extcrnal. Nymphx generally projecting externally. 
This family is subdivided into N. Solenaria, and $N$. Tellinaria.

\section{NYMPHACEA SOLENARIA. SANGUINOLARIA.}

GENERIC CHARACTER: Shell transverse, subliptical, slightly gaping at the lateral extremities; superior margin arched, not parallel to the lower; two approximate teeth in each valve. This genus is distinguished from the Solens by the superior margin not being parallel to the inferior; they also gape but little at the lateral extremities.

* S. VESPERTINA. Tellina Variabilis. Turt. Lin. T. Depressa. Pen. Brit. Zo., vol. 4, pl. 47, fig. 27. Solen Vespertinus. Mont. Test. Brit., vol. 1, p. 54. Sanguinolaria V. Flem. Brit. An., p. 460. Found by Montagu at Falmouth; where it is scarcelv uncommon.

S. DEFLORATA. Venus D. Turt. Lin. Pen. Brit. Zo., vol. 4, pl. 57, fig. 54. Stew. Elem., vol. 2, p. 381. Mont. Test. Brit., vol. 1, p. 123, pl. 3, fig. 4. S. D. Flem. Brit. An., p. 461.

Montagu says, "we found a perfect, recent, specimen at Falmouth, it was dredged from the harbour of that place, but is no doubt a very rare species in England."

\section{PSAMMOBIA.}

GENERIC CHARACTER: Shell transverse, eliptical or oblong oval, rather flat, slightly gaping at both sides; beaks prominent. Two cardinal teeth on the left valve, and one entering tonth on the opposite valve.

* P. FERROENSIS. Tellina Incarnata, Pen. Brit. Zo., vol.. 4, pl. 47, fig. 31. T. Ferroensis. Stew. Elem., vol. 2, p. 371, T. Fervensis. Mont. Test. Brit., vol. 1, p. 55. P. Ferroensis. Flem. Brit. An., p. 438. Without being rare, it scems somewhat scarce, perlaps from being easily destroyed. I lave found single valves adhering to the byssus of the Pinna, from the depth of 50 fathoms; and I once took it from the stomach of the Picked Dog-fish.

* P. FLORIDA. Flen. Brit. An., p. 437. In St. Austle bay, and near Falmouth. A specimen marked for me at the British Museum, Ps. Bilineata, not uncommon in Cornwall, seems to be of this species,

* P. SOLIDULA. Tellina Carnaria. Pen. Brit. Zo., vol.4, pl. 49, fig. 32. T. S. Mont. 'Test. Brit., vol. 1, p. 63. 'T. C. Stew. Elen., vol. 2, p. 373. P. S. Flem. Brit. An., p. 438. Abundant at Par.

* P. ROTUNDATA. Tellina R. Mont. Test. Brit., rol. 1, p. 71, pl. 2, fig. 3. P. R. Flen. Brit. An., p. 438. I have found it at Par; and have obtained it from the byssus of the Pinna. 
P. Costatula. Flem. Brit. An, p. 437. A single valve was supplied to me by Mr. Peach from Grorsan.

P. STRIGILLATUS. Flem. Brit. An., p. 439. Fleming reports it from Torbay and Cornwall:

\section{NYMPHACEA TELLINARIA.}

THE FIRST DIVISION IS MARKED BY HAVING ONE OR TWO LATERAL TEETH.

\section{TELLINA.}

GENERIC CHARACTER: Shell transverse or orbicular, in general ratlier flat; the anterior side angular, with a flexuous and irregular fold on the margin. One or two cardinal teeth in the same valve; two lateral teeth, often distant.

* T. SQUALIDA. Mont. Test. Brit., vol 1, p. 56. Flem. Brit. An., p. 436. I have found it at Par.

* T. DONACINA. T. Trifasciata. Pen. Brit. Zo., vol. 4, p. 88. T. D. Mont. Test. Brit, iol. 1, p. 58. Stev", Elem., vol. 2, p. 371. Flem. Brit. An., p. 435. I havo obtained it from the byssus of the Pinna from deep water: and also near the land, but rarely. Montagu found it in Falmouth harbour.

* T TENUIS. T. Planata. Turt. Lin. Pen. Brit. Zo., vol. 4, pl. 48, fig. 29. Stew Elem., vol. 2, p. 370. Mont. Test. Brit., vol. l, p. 59. T. T. Flem. Brit. An., p 436. It is in abundance at Par, but far less common eastward.

T. STRIATA. Turt. Lin. Mont. Test. Brit., vol. 1, p. 60. Flem. Brit. Ap., p. 436. Rare. I found two or three single valves at Par.

* T. CRASSA. Turt. Lin. Pen. Brit. Zo., vol. 4 pl. 48, fig. 28. Mont. 'Test. Brit., rol. 1, p. 65. Flem. Brit. An., p. 436. Common.

T. PUNICEA. Turt. Lin. T. Læata. Mont. Test. Brit, vol. 1, p. 57. Flem. Brit. An., p. 435. Rare. I have procured what I suppose to be this shell, from the byssus of the Pinna.

* T. FABULA. Turt. Lin. Mont. Test. Prit., vol. 1, p. 61. Flem. Brit. An., p. 435. Rather common.

\section{LUCINA.}

GENERIC CHA RACTER: Shell suborbicular, with unequal sides; beaks small, pointed, oblique. Two direrging cardinal teeth (one of them bifid) which vary or disappear with age. Most species have two lateral teeth, the posterior nearest the cardinal; some have no lateral teeth. Two very separate muscular impressions, the posterior produced in the form of a band, sometimes very long, and extending to the middle of the valve. Ligament external. 
* L. IfADULA. Tellina Radula. Mont. Test. Brit., vor. 1, p. 68. pl. 2, fig 1, 2. Lucina R. Hem. Brit. An., p. 411. Montagn found it in ahumbance at Falmouth; and I have Qbtained it on the east coat.

L. FLEXUOSA. Tullin: F. Mont. Test. Brit., vol. 1, p. 27. Eucina F. Flem. Brit. An, p. 442.

Montagu says "It is abunlant in the sand of Falmouth larbour; it is less common in other districts.

L. PISIFORMIS. Cartium Discors, Mont. 'Test. Brit., vol. I, p. 84. L P. Flem. Brit. $A$ n., p. $44 z$.

Montagn says "we hesitate to determine this shell to be actually Eoglish, haring only found one dead specimen in sand at Falmonlh, taken from the harbour."

L. ARCUATA. ('arlium A. Mont. Test. Brit., vol. I, p. 85, pl. 3, fig. 2. Lucina A. Flem. Brit. An., p. 442. "We found this elegant species in Falmonth harbour, dredgerl, up with sand for manure; but not common." Montagu.

L. LACTEA. Telina L. Lin. Mont. Test. Brit, vol, I, p. 10, pl. 2, fig. 4. Loripes Lacteus. Flem. Brit. An., p. 430. Starcely uncominon.

\section{DONAX.}

GENERIC CHARACTER: Shell transverse, equal valved, unequal sided; anterior side very short and obtuse. Two cardinal teeth either in both valves, or only in one; one or two lateral teeth, more or less distant. Ligament short, external, inserted in the place occupied by the lunula.

This genus is characterized by its rather flattened, and almost triangular shell, and by haring at the hinge, beside the cardinal teeth, one or two rather distant lateral teeth, separated from the cardinal teeth, and analogons to the lateral teeth of the Mactræ, Succineæ and Tellinæ. The ligament of the Donaces and Teline, is always on the shortest side of the shell, but in the Veneres and Cytherex, it is on the longest. The Donax has not the flesuons fold of the Tellina. Journal of Science, vol. 14, p. 307.

* D. TRUnculus. Turt. Lin. Pen. Br. Zo., vol. 4, pl. 55, fig. 45. Mont. 'Jest. Brit., vol. 1, p. 103. Flem. Brit. An., p. 433 . On some part of the coast this is rare; but it is found at Par in abundance.

D. DENTICULATA. Turt. Lin. Pen. Brit. Zo., vol. 4, pl. 55, fig. 46. Niont. 'Test. Brit., rol. 1, p. 104. Stew. Elem., vol. 2, p. 378. Flem. Br. An., p. 433. This is inserted on the authority of $\mathrm{Da}$ Costa; neither Montagu nior myself having ever found a specimen.

* D. COMPLANATA. Mont. Test. Brit., rol. 1, p. 106. Elem. Brit. An., p. 434. Rare. Montagu found it at Fatmouth and Looe; and among a collection of small shells 
which a child procured for me on the beach at Par, I found five specimens of the single valves.

D. RUBRA. Flem. Brit. An., p. 434. I have only obtained a single valve of this rare species.

The SeCond DIVISION IS MARKED By HAVING No LATERAL TEETH.

\section{CAPSA.}

GENERIC CHARACTER: The Shell transverse, equalvalved, close; the hinge with two teeth in the right valve, and one entering bifid tooth in the other; no lateral teeth. Ligament external.

C. CASTANEA. Donax C. Mont. Test. Brit. vol. 2, p. 573. C. C. Flem. Brit. An. p. 434.

Montagu observes, "It appears to be a rare species, as only one mutilated specimen of a single valve had come under obsesvation till very lately, which was taken at Falmouth in Cornwall, five or six years ago; from which we did not chose to hazard a description: a few other specimens, recently found at St. Austle bay in that county, and on the coast of Devon, has enabled us to add it to the Catalogue of British Shells."

\section{CRASSINA.}

GENERIC CHARACTER: The shell suborbicular, equalvalved, with scarcely equal sides, close. Two strong diverging cardinal teeth in the right valve, and two very unequal teeth on the other. Ligament on the longest side external.

* C. SUlCATA. Venus S. Mont. Test. Brit., vol. I, p. 131. Astarte S. Flem. Brit. An., p. 439. It is introduced on the authority of $\mathrm{Da}$ Costa.

- C. DANMONIAE. Astarte D. Flem. Brit. An., p. 440. Fleming describes the shell as white, with a dark brown cuticle; but I have seen it no otherwise than a dull yellow. Common in the trawl, at Falmouth.

C. TRIANGULATA. British Museum. Length about a line, form nearly triangular, with the margin rounded, toothed at the meeting of the valves; beaks prominent; valves smooth, with concentric lines, not raised into furrows. Colour pale yellow. Rare.

\section{SECTION III.}

\section{CONCHIFERA LAMELLIPEDA.}

Foot of the animal broad and thin.

\section{CONCHZE.}

With three cardinal teeth at least in one valve, and as many or less in the other; sometimes with lateral teeth. 
The Concliæ are dirided into Fluviatiles and Marina.

\section{CONCHZE FLUVIATILES.}

The shells covered with a false epidermis, and having two lateral teeth near the hinge.

\section{CYCLAS.}

GENERIC CHARACTER: Shell ovate, globose, transverse; equalvalved, the beaks tunid; cardinal teeth very small, sometimes scarcely perceptible; occasionally two in each ralve, one of them plaited in two; sometimes only one plaited or lobed tooth in one valve, and two in the other; lateral teeth transversely elongated, compressed, lainellar. Ligament external. Mr. Gray's character of his Cycladre is, the shell subcordate, porcellaneons, thin, covered with a hard, olive, horny periostraca; hinge teeth two or three, diverging; lateral teeth distinct, laminar.

C. CORNEA. Tellina Cornea. Turt. Lin. Pen. Brit. Zo., vol. 4, pl. 49, fig. 33. Cardium C. Mont. Test. Brit., vol. 1, p. 36. C. C. Flem. Brit. Au., p. 452. Gray's Turton's Manual of land and fresh water shells, p. 280 , pl. 1, fig. 2. There are few situations in Cornwall, in which the Cycladx can find a proper habitation; and lience the present species is in a great measure local. I have obtained it, by favour of a Lady, from near Helston.

\section{PISIDIUM.}

GENERIC CHARACTER: The shell suboral, wedgeshaped, unequal sided; the teeth as in Cyclas.

P. AMNICUM. Cardium A. Mont. Test. Brit., rol. 1, p. 86. Cyclas A. Flem. Brit. An., p. 453. P. A. Gray's Turt., p. 285, pl. 1, fig. 5. In the Stappool, near Falmouth.

\section{CONCHZE MARINZE.}

Generally with no lateral teeth: sometimes the wholo shell, except the beaks, covered with epidermis.

CYPRINA.

GENERIC CHARACTER: The valies equal, the shell obliquely teartshaped, the beaks obliquely curved. Three unequal cardinal teeth, approaching at their hase, slightly diverging abore. One lateral tooth, distant from the binge, on the anterior side, somctimes obsolete. Callositics of the Nymphre large, arched, ending near the beaks by a pit. Ligament external, partly sunk under the beaks.

By haring an epidernis, and their sometimes almost obsolete lateral tooth, the Cyprina are somewhat allied to the fresh water Concha.

* C. ISLANDICA. Verus I. Turt. Lin. V. Mercenaria Pen. Brit. Zo., vol. 4, pl. 53, fig. 47. V. I. Mont. Test. 
Brit., vol. 1, p. 114. C. I. Flem. Brit. An., p. 443. Scarcely abundant; but taken in Trawls and on the lines of fishermen.

C. MINIMA. Venus M. Mont. Test. Brit., vol. 1, p. 121 pl. 3, fig. 5. C. M. Flem Brit. An., p. 444.

Montagu says, "It is a rare species, which we have only found sparingly at Falmonth, dredged from the barbour, alive."

\section{CYTHER $\mathbb{E}$.}

GENERPC CHARACTER: The valves equal, the shell suberbicular, triangular or transverse, four cardinal teeth on the right valve, three of them diverging, approaching at their base, and one, perfectly insulated, situated near the lunula. Three diverging cardinal teeth on the other valve, with a rather distant oval pit, parallel to the margin. No lateral teetb.

* C. CHIONE. Venus C. Turt. Lin. Mont. Test. Brit.. vol. 1. p. 115. Flem. Brit. An., p. 144. Queens. Common. c. OVATA. Venus Ovata. Pen. Brit. Zo., vol. 4, pl. 56, fig. 56. Flem. Brit. An., p. 445. Dead shells common. E. REFleXA. Venus R. Flem. Brit. An., p. 446. Rare. I possess a single valve, obtained from the byssus of a Pinna from deep water.

I have classed this species in the genus Cytheræa, from the circumstance that my specimen was thus marked, by a gentlemen well acquainted with conchology. In many instances, indeed, the distinctions of these genera cannot be strictly preserved; and therefore I venture to place here a species, with which, without close investigation, it may be confounded. This is the Venus Prideauxiana, as marked by the same kind friend. The description of C. Reflexa is: The shell compressed, length (from beak to margin). $1 \frac{1}{8}$ inch ; width $1 \frac{3}{8}$ inch; dorsal margin behind the beak approaching to straight; concentric ridges rising into thin plates: their edges bent upward on the forepart, waved and deflected towards the dorsal margin. Colour pale brown. On the inner margin a fine crenulation, not extended to the border. V. PRIDEAUXIANA is in length $7 \cdot \frac{1}{2}$ eighths of an inch from beak to margin, and $9 \frac{1}{3}$ eighths broad: dorsal margin. about equally straight as the former, but longer, by which the circular sweep is less. The lunula of the former is produced into a line that joins, with scarcely an interruption, the margin with the beak; whereas in the latter it is narrow and retiring. The concentric ridges, though in a smaller shell, are more numerous, and far less elevated. Colour pale brown, with two or three obscure marks of the longitudinal lines so often seen on the Veneres. With$\mathrm{in}_{\mathrm{s}}$, the margin of the lunula is finely crenulated, as is also. 
the circular margin of the shell, but less fincly and regus larly than the former.

of this shell also, 1 hare scen but a single valve, obtained from the byssus of a Pinna from deep water.

\section{VENUS.}

GENERIC CHARACTER: The shell with the valves equal, sides unequal, transverse or suborbicular. Three approximate cardinal teeth in each valve; the lateral teeth diverging at the summit, ligament external, covering the scutcheon.

V. CASSINA. V. Erycina, variety. Pen. Brit. Zo., vol. 4, pl. 54, fig. 48. V. C. Flem. Brit. An., p. 446. Not common.

* V. VERrucosa. Turt. Lin. V. Erycina. Pen. Brit. Zo., vol. 4, pl. 54, fig. 48. V. V. Mont. Test. Brit., vol. 1, p. 112. Borlase's Nat. Hist. Corn. pl. 27, fig. 32. Flem. Brit. An., p. 446. Common on the shores east of the Lizard, and abundant in the soil dredged from Falmouth harbour.

* V. FASCIATA. V. Paphia. Turt. Lin. Mont. Test. Brit., vol. 1, p. 110. V. F. Flem. Brit. An., p. 447. Common. It frequently creeps into crabpots in search of the bait.

* V. GALLINA. Turt. Lin. V. Striatula. Mont. Test. Brit., vol. 1, p. 113. V. G. Flem. Brit. An., p. 448. Common; and with the same habits as the last.

V. SUBCORDATA. Mont. Test. Brit., vol. 1, p. 121, pl. 3, fig. 1. Flem. Brit. An., p. 447. Found by Montagu in sand from Falmouth harbour.

V. GRANULATA. Turt. Lin. Mont. Test. Brit., vol. 1, p. 122. Flem. Brit. An., p. 447. Scarce; found by Montagu at Falmouth.

V. UNDATA. Turt. Lin. Pen. Brit. Zo., vol. 4, pl. 55, fig. 51. Mont. Test. Brit., vol. 1, p. 117. Flem. Brit. An., p. 448. Not common. Montagu found it at Falmouth.

* V. AUREA. Turt. Isin. Mont. Test. Brit., vol. 1, p. 129. Flem. Brit. An., p. 449. This shell seems to be locally common. Montagu found it in sand from Falmouth harbour ; from whence also I have obtained it, and from St. Austle bay.

\section{CARDIACEA.}

Cardinal teeth irregular, either in form or situation, and generally accompanied by one or two lateral teeth.

\section{CARDIUM.}

GENERIC CHARACTER: Shell with equal valves, sumewhat heart shaped; beaks prominent; internal margin of 
the valces toothed or plaited. Hinge with four teeth on each valve: the two cardinal approximate and oblique, articulating crosswise with the corresponding teeth of the other valve; the two lateral teeth distant, entering. The ligament is external and very short; and there are two faint muscular impressions.

* C. EDULE. Turt. Lin. Pen. Brit. Zo., pl. 50, fig. 41. Mont. Test. Brit., vol. 1, p. 76. Flem. Brit. An., p. 422. Common Cockle. Common in harbours that have a stream of fresh water; from whence they are taken in abundance, and carried to market.

This shell varies so considerably, as almost to raise the suspicion of a difference of species. In its younger state it is about equal-sided, the ridges smooth; but when fully grown in an undisturbed situation, the binge is nearer one end, the opposite margin produced, and the ridges thickly and regularly covered with raised transverse edges. A considerable quantity in this state, of large size, and mixed with Venerirupis Decussata, V. Virginea and others, were found with other ancient animal remains, in the stream work of Lover Pentewan, near St. Austle.

* C. ECHINATUM. Turt. Lin. Mont. Test. Brit., rol. 1, p. \%8. Flem. Brit. An., p. 420. Prickly Cockle. Not uncommonly taken in the Trawl.

* C. TUBERCULATUM, Nont. Test. Brit., vol. 1, p. 79, and vol. 2, p. 568. Flem. Brit. An., p. 421. The loose valves are scattered along our shores; and in some places in abundance, as in Lantivet bay, east of Fowey.

C. CILIARE. Turt. Lin. Mont. T'est. Brit., vol. 1, p. 80. Fleming supposes this to be the young state of C. Acu. leatum. Pen. Brit. Zo., rol. 4, pl. 50, fig. 39. Mont. Test. Brit., vol. 1, p. $7 \%$. A shell so slight and fragile as this, will scarcely be found abundant on the shore; bence the only place at which $I$ have discovered it, is Pentewan.

* C. EXIGUUM. C. Pygmenm. Turt. Lin. C. E. Mont. Test. Brit., vol. 1, p. 82. Flem. Brit. An., p. 422. This shell belongs to Lamark's sub-section, in which the valve has a carination or angle, dividing the surface into two unequal longitudinal spaces. Not uncommon near low water mark.

* C. MEDIUM. Turt. Lin. Mont. Test. Brit., vol. 1, p. 83. Flem. Brit. An., p. 422. This shell bears inuch resemblance to the last; but it is larger, and without tubercles or spines. I found it in abundance in the soil taken up for the purpose of deepening the harbour, at Falmouth.

C. TODOSUM. Riont. Test. Brit., rol. 1, p.81. "With a llat suborbicular shell; colour rufous while, with 24 ribs, corercd with dose set, obtusc tubercles. Inside white 
glossy ; margin strongly denticulated. We found this new species amongst sand from Falmouth harbour. Diameter three quarters of an inch. Although this shell bears some resemblance to the young Echinatum, it must not be confounded; the young of that species is always more globose or concex; the ribs are more sharp, and the tubercles more pointed and distant." Montagu. Dr. Fleming is disposed to regard it as the young of $\mathbf{C}$. Muricatum.

* C. LIEVIGATUM. Pen. Br. Zo., vol. 4, pl. 51, fig. 40. Mont. Test. Brit., vol. 1, p. 88. Flem. Brit. An., p. 423. On some parts of our coast, and especially at Hannafore, apposite Lone Island, I find single valves thrown on shore in abundance.

C. FASCIATUM. Flem. Brit. An., p. 422. British Museum. Obtained from near the Land's end. HIATELLA.

GFNERTC CHARACTER: Shell with the valves equal, the sides unequal, transverse, gaping at the anterior margin. Hinge with one small tooth on the right valve, and two rather larger, on the left. Ligament external.

* H. ARcTiCA. Solen Minutus. Turt. Lin. Mont. Test. Brit., vol. 1, p. 53, pl. 1, fig. 4. H. A. Flem. Brit. An., p. 46i1. Crouch's Intro. to Lam., pl. 8, fig. ti. Not uncommon, burrowed in stone.

H. PR ALCISA. Mytilus P. Mont. Test. Brit, vol. 1, p. 165, pl. 4, fig. 2. Great confusion exists in the writings of naturalist, concerving the two species of Hiatella here given, and Saxicava Rugosa; some supposing them to be no more than one species, while by others they are separated into different Genera. Under these circumstances, and having examined them when apparently uninfluenced by foreign bodies, I have judged it best to follow the opinion of Montagu, who considers them distinct. H. Præcisa is common on rocks near low water mark, attached to the roots of corrallines by the aid of a byssus.

\section{ISOCARDIA.}

GENERIC CHARACTER: The shell heartshaped, transverse, gaping at the upper margin, the valses equal, the beaks distant, divering, spirally turned on one sicie; two flat, entering, cardinal teeth, one of them curved and sunk under the beak; one elongated lateral tooth, situated under the corselet. Ligament external, forked on one side.

I. COR. Chama Cor. Turt. Lin. Mont. Test. Brit, vol. 1, p. 134. I. C. Flem. Brit. An. p. 418. Crouch's Intro. pl. 8, fig. 7. Very rare. I have seen a specimen which, 
I was assured, was taken near Falmouth, and am informed that it is not uncommon at Helford, buried at some depth in the sand.

\section{A RCACEA.}

Cardinal teeth small, numerous, entering, and disposed on each valve in a straight, arched or broken line.

\section{ARCA.}

GENERIC CHARACTER: Shell transverse, the valves nearly equal, sides unequal, beaks distant, separated by the facet of the ligament. Hinge linear, straight, without ribs at its extremities, and furnished with a series of many entering teeth. Ligament wholly external.

* A. NO E. Turt. Lin. Borlase's Nat. Hist. Corn., pl. 28, fig. 16. A. Tortuosa, Pen. Brit. Zo., vol. 4, p. 97. A. N. Mont. Test. Brit, vol, 1, p. 139, pl. 4, fig. 3. Flem. Brit. An., p. 397. Scarce. I have obtained it. from Pridmouth, near Fowey; and about the Land's end, chiefly from cavities in stones from deep water.

A. LACTEA. Turt. Lin. A. Barbata. Pen. Brit. Zo., vol. 4, pl. 58, fig. 59. But the reference misplaced to A. Nucleus. A. L. Mont. Test. Brit., vol. 1, p. 138. Flem. Brit. An., p. 398.

"This shell" says Montagu, "is found in great abunilance in some parts of the south coast of Devon; and not frequently on that of Cornwall; particularly about Falmouth; but live shells, or double valves with the epidermis on, are rare." It is scarce on other parts of the coast.

* A. FUSCA. Flem. Brit. An., p. 397; who quotes Borlase's Nat. Hist. Corn., pl. 28, fig. 15 ; and Montagu's supplement. Not uncommon in the crevices of stones from deep water.

The observance of a living specimen of this species enables us to discern the variety of manner in which the different genera of bivalves expand, or take their prey. The arca lies with the hinge downward, the hauriant vessel pointing obliquely up, with little powers of motion; whereas the Cycladæ and Kelliæ, walk and even climb, with celerity and firmness, the hinge being upward, and the foot advanced for the purpose of taking hold-fast, and drawing it forward: the heel at the same time being engaged in keeping it steady. Pectens and Oysters preserve the hinge horizontal, the former being capable of little, and the latter of no motion. When set at liberty, the first act of the Mytilus and Pinna, is to secure themselves against future motion; but the arcæ have no better method of securing this state of rest, than taking refuge in a cavity, from which their subsequent growth ever after prevents their escape. 
A. RHOMBEA. Marked for me by J. E. Gray, Esq. of the British mnseum. It is the largest of the British arca that has come under my notice, measuring in its longest diameter one inch and four-tenths, and in breadth nine-tenths of an inch, figure of the rhomb across the hinge one inch and one-tenth; surface of the valves as if worn, by the friction of opening in the cavity of the stone in which it was included, and hence the vestiges of striæ were but few. About the middle of the free edges of the valves is a vacancy rounded off into a long oval; this portion, when the valves are closed being filled by a semicalcareous operculum formed on the summit of the tongue or protrusive organ. A border, of regular form and about one-tenth of an inch wide, circles the free margin of the valves, being covered with short bristles in narrow lines. Some marks of these hairs appear on other parts, especially on the terminal angle of the opening. Colour dull yellow, bristles brown.

This, the only specimen which $\mathrm{I}$ have met with, was found in a cavity originally formed by a Pholas in sandstone from deep water, and was for some time alive in my possession.

\section{PECTUNCULUS.}

GENERIC CHARACTER: Shell orbicular, almost lenticular, the valves equal, sides almost equal, close. Hinge arched, with a series of many, oblique entering teeth, the middle ones obsolete, nearly obliterated. Ligament external. This genus is distinguished from arca by its orbicular form, and by the hinge being arched instead of straight. The teeth also are less numerous, more separate and larger; and they never gape. The beaks are not very distant, yet are always separated by an external. narrow, angularly furrowed, rather hollow facet, to which the ligament is attached, and which distinguishes the Pectunculi from the genus Nucula; the ligament of which is partly interior, and which las no facet between the beaks.

* P. PILOSUS. Arca P. Turt. Lin. A. Glycimeris. Pen. Brit. Zo., vol. 4, pl. 58. fig. 58. A. P. Mont. Test. Brit., vol. 1, p. 136. P. P. Flem. Brit. An., p. 400. Common, and locally abundant.

\section{NUCULA.}

GENERIC CHARACTER: The shell transverse, triangularly ovate or oblong, the valves equal, sides unequal; no facet between the beaks; hinge linear, broken, many toothed, interrupted in the middle by an obliquely extending spoonshaped pit; the teeth numerous, often produced as in the Pectens; the beaks contiguous, curved backwards, Ligament marginal, and partly internal, inserted in the pit or spoon of the binge. 
"N. NUClEA, Arca N. Mont. Test. Brit., vol, 1, p. 141. N. N. Flem, Brit. An., p. 401. Not uncommon.

NAIADA.

Fresh Water Shells; the linge with an irregular, simple or divided cardinal tooth, and a longitudinal one, which extends under the corselet; sometimes no tooth; or with irregular granular tubercles through its leggtb. Muscular impression posterior, compound; the beaks decorticated or eroded.

UNIO.

GENERIC CHARACTER: The shell transverse, with equal valres, unequal sides, free; beaks decorticate, almost eroded; nuscular impression posterior, compound; hinge with two teeth in each valre; one cardinal, sliort, irregular, simple, or divided into two substriated; the other elongated, compressed, lateral, prolonged under the corselet. Ligainent external.

* U. MARgaritiferA. Mya M. Turt. Lin. Pen. Brit. Zo., vol. 4, pl. 43, fig. 13. Mont. Test. Brit., vol. 1, p. 33. Alasmodion M. Flen. Brit. An., p. 41\%. Gray's Turt., p. 293, pl. 2, fig. 9. River Nuscle. In some of our larger rivers, as the Camel and Tamar.

\section{CONCHIFERA UNIMUSCULOSA.}

With one muscular impression, nearly in the middle of the interior.

\section{IB Y TILACEA.}

The Ligament at the hinge subinternal, marginal, linear, very entire, occupying a great part of the anterior margin; rarely foliated.

\section{MODIOLA.}

GENERIC CEARACTER: Shell subtransverse, with equal valves, regular, the posterior side very short : beaks nearly lateral, depressed on the short side; hinge toothless, lateral, linear. Ligament cardinal, almost internal, in a marginal canal; one sublateral muscular impression, lengthened, axeshaperl.

* M. VUlgaris. Mvtilus Modiolus. Turt. Lin. Pen. Brit. Zo., rol. 4, pl. 66, tig. 77. Mont. Test. Brit., rol. 1, p. 163. N. V. Flem Brit. An., p. 412. Scarcely comnon, and I have nerer obtained it of the size mentioned by Pennant and Montagu. The iescription of a specimen from deep water, differs so greatly from theirs, as almost to surgest the susvicion of a different species. The length was an inch and half, the substance thin and apparently brittle; the surface smooth, with ro perceptible epidernis. When drawn up it was attached to a bed of fine gravel reclining on a stone; and having becn taken with a took, it 
had not been disturbed when bronght to me, There was no byssus. The same species is sometimes found on the shore.

* M. DISCREPANS. Mytilus D. Mont. Test. Brit., vol. 1, p. 169. Modiola D. Flem. Brit. An., p. 413. Abundant on rocks, attached by a byssus to the stems of the common Coralline. It is also frequently found embedded in the substance of a species of ascidia : in a manner not easily to be accounted for, but in which situation it grows to a much larger size than when openly exposed, and with much more beautiful colours. When thus enclosed, the syphon pierces. the tunic of the animal, and thus preserves its commuication with the water.

M. DISCORS. Mytilus D. Mont. Test. Brit., vol. 1, p. 167. Modiola D. Flem. Brit. An., p. 413. Common, but less abundant than the last species; I have never found it buried under the tunic of an Ascidia, like the last named species.

M. GIBBSIII. Flem. Brit. An., p. 413, Of this rare species I have seen only one specimen, presented by a Lady. M. BARBATUS. Mytilus Curtus. Turt. Lin. Pen. Brit. Zo. vol. 4, pl. 64, fig. 76. M. B. Mont. Test. Brit., vol. 1, p. 161 .

Dr. Fleming confidently pronounces this to be a variety of Modiolus Vulgaris; with which opinion neither Montagu's nor mine can agree. It is not rare; but whether the following is a younger growth or separate species, must be left for further research. It is provisionally named, for it differs considerably from a foreign shell marked M. Barbatus in the museum of the Royal Institution; and I have found the Cornish shells so named, so commonly fixed amongst specimens of Mytilus Incurvatus, a shell which from its exposed situation soon becomes naked and worn, that I have doubted whether it be not the young of that species; an opinion which seems to have been held by Pennant.

* M. MINUTUS. It is minute; and many specimens were found among a multitude of the Kellia rubra, studding the fibres of a small green sea weed, on which they appear to liave been feeding. It is about as deep as long, and along the side of the hinge thinly studded with short firm hairs. It is not attached by a byssus, and seems capable of motion, like the Kellia.

\section{MYTILUS.}

GENERIC CHARACTER: Shell longitudinal, the valves equal, regular, pointed at the base, fixed by a byssus. Boaks almost strait, terminal, pointed. Hinge lateral, usually without teeth. Ligament marginal, subinternal. One elongated, clavate, sublateral muscular impression. 
* M. EDUlis. Turt. Lin. Pen. Brit. Zo., vol. 4, p!. 63, fig. 33. Mont. Test. Brit., vol. 1, p. 159. Flem. Brit. An., p. 411. Common Pinscle. Naturalists have not yet agreed whether we have one or several species of Muscle ; it is therefore judged best to speak of the several varieties found on our coast, as if they were species, by which means we shall avoid the great, though least common error, of confounding together several separate kinds : a minute examination of the animal of which will alone decide the question of their specific identity.

Dr. Fleming's character of this species refers to the M. Pellucidus of Pennant, pl. 63, fig. 75; a variety of common occurrence-rather than to the more isual appearance of this shell. fish, which is without longitudinal coloured bands. Beds of muscles are found in barbours and the mouths of rivers, where from the frequent change of salt and fresh water, they attain their highest perfection; and from whence they are taken for food, and to be used as bait by fishermen. There is no shell-fish that so frequently disagrees with the stomach, as the muscle; and the symptoms it produces are often of the most violent kind.

M. SUBSAXATILIS. Williamson in Mag. Nat. Hist. O. S. vol. 7, p. 354. The difference between this, and the long and narrow form of a variety that is of frequent occurrence at Helford, and sone other parts of our coasts, would indicate specific distinction: but the more common form intermediate between them, is united to either by such gradual marks of approach, that nothing beyond doubt can be admitted,

" M. INCURVATUS. Turt. Lin. Pen. Brit. Zo., vol. 4, pl. 64, fig. 74. As this species assumes much variety of form, it would not be difficult to obtain specimens that could not easily be distinguished from some of the common muscle; but their habits differ greatly. So far is this from seeking, as the former, perpetual immersion, it selects a station so high above the low water tide-mark, that in many instances it must remain dry for not less than ten hours, The chosen crevices also are more frequently on the dry ridge, than in pools; on the summit of the rock than at the base. Montagu speaks of it as occurring single; but in my observation they congregate in considerable numbers

\section{PINNA.}

GENERIC CHARACTER: Shell longitudinal, wedge shaped, the valves equal, gaping at the summit, pointed at the base, the beaks straight, hinge lateral, without teeth. Ligament marginal, linear, very long, almost internal.

* P. INGENS. Pen. Brit. Zo., vol. 4, pl. 59, fig. 80; but marked by mistake P. Fragilis. Mont Test. Brit., 


\section{5}

vol. 1, p. 180. Flem. Brit. An., p. 406. It is called by fishermen Cappa Longa, from its resemblance to the Razor shell, the larger Solen; which formerly bore that name, as Lister informs us it also did at Venice.

The synonyms of the British Pinuæ have become so confused, that to prevent further mistake it is judged necessary to give minuter descriptions of them, than of the other species of shells described or referred to in this work. The Greater Pinna, in the specimen selected, is in length on the side of the hinge, 12 inches; but the longest in my collection measures 17 inches. Lengih of the specimen on the wider end, 13 inches : from the point to the remotest distance $14 \frac{3}{4}$ inches; greatest girth $16 \frac{3}{4}$ inches: form of the outline. somewhat that of a scimitar or cleaver. The longitudinal striæ are well marked, but irregular, and more commonly without concave spines. Colour light brown, dark near the pointed end, this colour passing upward in broad stripes, I have not had an opportunity of comparing this shell with that from the Mediterranean, which bears the same name; but the byssus of the latter is very different, being far more soft, silky, and in colour a rich yellowish brown, whereas that of our coast is rigid and of an intense black.

Montagu's account of this species is as follows: "We discovered a bed of these shells in Salcomb bay, in Devonshire; where they are called by the fishermen French muscles, or scallops. They lie on a gravelly bottom covered with mud and long sea-weeds; and are only to be got at particular times, when the sea recedes farther than usual. They stand upright, with the large end about an inch above the surface; tho lower end fixed by a very large strong byssus, so firmly attached to the gravel, that much force is required to draw them up; and most commonly the byssus is left behind. This beard is composed of numerous, fine, silk like fibres, of a dark purplish brown, two or three inches in length. The larger end of the shell is naturally a little open, and cannot be closed by art, but the animal is capable of effecting it, the beaks of the valves rarely cover each other exactly. The bank on which these shells are found, probably increases, so that the water leaves a greater part bare, at every spring tide, than formerly." This species is also reported as an inhabitant of Falmouth harbour; but it is found in the greatest abundance, at the distance of from three to six or eight leagues south of the Deadman point; where they stud the bottom in multitudes, with only two or three inches of the pointed end inserted into the soil. It is common for the line or hook to become entangled among these shells, and powerful effort is required to drag them from their attachment; which is only affected hy breaking the byssus, or tearing away the ground to which it is attached. 
In the latter case a rich harvest of shells is often afforded; but the pointed end of the pinna is usually broken off by the violence. It is perhaps owing to the different degree of solidity in the ground, that the shells living in the deeper water, are so much less buried, than those of which Montagu speaks; and one of the consequences may be a greater freedom of motion in the shell. Montagu observes, that the exposed end cannot be closed by art, but the animal is capable of effecting it; and observation has taught me that this is its method of obtaining food. In its ordinary position this opening is about two inches wide, exposing the contained animal, which occupies but a small portion of the cavity, and seems to offer itself as a prey to the first creature that may choose to devour it. Some fish is thus tempted to enter, but the first touch within is a signal for its destruction. The shell closes, not only at the side but top, the latter action being effected by the separation of the pointed ends; and the captive is either crushed to death or soon perishes from confinement. It was formerly believed that the Pinnotheres Pisum, a Parasitic Crab, had its residence within the shell of the pinna, and was the friend to whose intimation the pinna owed the knowledge of the presence of its prey. But of the many pinna I have had an opportunity of examining, I have never found one containing this crab; and Montagu has made the same remark. In one instance three or four pearls, perfectly round and of an intense black colour, were found in the mantle near the hinge.

* P. ROTUNDATA. Turt. Lin,, vol. 4, p. 302. This species, not hitherto recognised as British, differs from the last in form and texture : being more thin and brittle. The free margin is less circular or cleaver shaped, the sides being more parallel, and the open extremity simply circular. In some specimens the lower surface is thickly studded with concave spines, while others, even of less size, are without them; as is the case also, with the Pinna ingens; but no dependance, as specific marks, can be placed on the presence or absence of these appendages. The animal of this shell is sufficiently distinct from that of the former, to confirm their specific difference. It is less common than the former, and of somewhat less size, but occupies the same situation.

P. FRA GILIS. P. Pectinata. Mont. Test. Brit., vol. 1, p. 178. P.F. Flem. Brit. An., p. 406. This is smaller, and also much rarer, than either of the former.

\section{MALACEA.}

Ligament marginal, sublinear, either interrupied by indentations or serial teeth, or wholly simple. Shell subunequal valved, foliated. 


\section{7}

AVICULA.

GENERIC CHARACTER: Shell unequal valved, brittle, rather smooth; base transverse, straibht; the extremities produced, the anterior like a tail; a sinus in the left valve; hinge linear, one toothed; a cardinal tooth in each valve under the beaks. Facet of the ligament marginal, narrow, channelled, not traversed by the byssus.

AVICULA HIRUNDO. Flem. Brit. An., p. 405. A specimen of this rare shell, taken in Plymouth sound, is in the possession of Dr. Edward Moore.

\section{PECTINIDA.}

The ligament internal, or partly so. Shell in general regular, compact, not foliated.

\section{LIMA.}

GENERIC CHARACTER: The shell longitudinal, the valves nearly equal, eared, gaping slightly on one side between them; beaks distant, their internal facet inclined outwards; hinge without teeth. The cardinal pit partly external, receiving the ligament.

L. FRA GILIS. Flem. Brit. An., p. 388. It approaches to, but does not strictly correspond with the figure and description of Mr. Forbes, in the Mag. Nat. Hist., vol. 8, p. 594, fig, 65. Length one inch and three-tenths, breadth nine-tenths of an inch. The valves equal, oblique, inflated, thin but not brittle, scarcely marked with lines of growth, and with obscure, not pectinated longitudinal striæ; gaping at both sides, touching only at the ears, and extremity of the margin. Colour pale yellow. I obtained a single specimen from the trawl at Falmouth.

\section{PECTEN.}

GENERIC CHARACTER: The shell free, regular, the valves unequal, with ears; the lower margin transverse, straight; beaks contiguous; hinge without teeth; a cardinal triangular pit, wholly internal receiving the ligament.

* P. MAXimus. Ostrea M. Turt. Lin. Pecten M. Pen. Brit. Zo., vol. 4, pl. 59, a view of the under valve; Mont. Test. Brit., vol. 1. p. 143. Flem. Brit. An., p. 383. Scallop. Common in moderately deep water.

P. JACOB AeUs. Ostrea J. Turt. Lin. Pecten J. Pen. Brit. Zo., vol. 4, pl. 60, fig. 62. Mont. Test. Brit., vol. 1, p. 144. Flem. Brit. An., p. 388. Scarcely common.

* P. OPERCUlaris. Ostrea O. Turt. Lin. Pecten Subrufus. Pen. Brit. Zo., vol. 4, pl. 60, fig. 63. P. Opercularis, Mont. Test. Brit., vol. 1, p. 145. Flem. Brit. An., p. 383. Taken abundantly in trawls, and carried to market. 
* P. VARIUS. Ostrea V. Turt. Lin. Pecten V. Pen. Brit. Zo., vol. 4, pl.61, fig. 64. Mont. Test. Brit, vol, 1, p. 146. Flem. Brit. An., p. 384. Less abundant.

P. LINEATUS. Mont. Test. Brit., vol. 1, p. 14\%. Flem. Brit. An., p. 383. Scarcely common. I have only seen it at Falmouth.

P. OBSOLETUS. Ostrea O. Turt, Lin. Pecten $O$. Pen. Brit. Zo., vol. 4, pl. 61, fig. 66. Flem. Brit. An., p. 385. Rare.

* P. LEVIS. Ostrea L. Pecten L. Pen. Br. Zo., vol. 4, 102. Mont. Test. Brit., vol. 1, p. 150, pl. 4, fig. 4. This very pretty shell is not uncommon; but is subject to great variety of colour, though always beautiful.

* P. SINUosus. P. Pusio. Pen. Brit. Zo., vol. 4, pl. 61, fig. 65. P. Distortus. Mont. Test. Brit. vol. 1, p. 143. P. S. Flem. Brit. An., p. 384. By Sowerby constituted the type of the Genus Hinnites. Common, attached by the lower valve to rocks, or more frequently to eschara fuliacea. It is subject to apparent distortion in its growth; but it acquires the length of abont a quarter of an inch before the irregularities begin, and afterwards becomes waved without regard to the evenness of its situation. It may be known at any stage by the ribs dividing in their progress, into smaller striæ, of nearly alternate sizes.

P. TUMIDUS. Flem. Brit. An., p. 314, described from Dr. Turton. Not uncommon on the shell of the pinna, but overlooked from its minute size. In their young state the Pectens are moored to their situation by a byssus; but when loosened by accident or nature, it is not renewed, and they are capable of some degree of motion,

OSTRACEA.

Ligament wholly or partly within. Shell irregular, foliated, sometimes very thin.

\section{OSTREA.}

GENERIC CHARACTER: The shell adhering, valves unequal, irregular; beaks distant, becoming very unequal by age; upper valve smallest, generally flat, and gradually advancing forward during the life of the animal. Hinge withont teeth. Ligament partly internal, inserted in the cardinal pit of the valves; pit of the lower valve increasing by age, sometimes to a great length.

* O. EDULIS. Turt. Lin. Pen. Brit. Zo., rol. 4, p. 102. Mont. Test. Brit., vol. 1, p. 151. Flem. Brit. An., p. 392. Oyster. Common on most parts of our coasts, and at all depths. It is found on the Pinna at the degth of $50 \mathrm{fa}-$ thoms, The oyster is cultivated for sale on the Tamar, at Falmouth and Heliord.

O. PARASITICA. Flem. Brit. An., p.392. Less common. 
ANOMIA.

GENERIC CHA RACTER: Valves of the shell unequal, irregular, operculated, adhering by the operculum; smaller valve perforated, usually flat, having a hole close to the beak; the other valvelarger, coneave, entire. Operculum small, elliptical, bony, connected with the internal muscle, and fixed to solid bodies.

Properly speaking, the perforated valve is to be regarded as the lower one. And beside the muscular attachment of the animal to the operculum (which is only the thickened extremity of the tendon) the two valves are connected by an inner cardinal limament.

* A. EPHipPIUM. Turt. Lin. Pen. Brit. Zo., vol. 4, pl. 62. Mont. Test. Brit., vol. 1, p. 155. Flem. Brit. An., p. 395. Common. The largest specimens I have seen were from l'innæ, in deep water.

* A. CEPIE. Flem. Brit. An., p. 395. This well marked species seens to bave been overlooked or confounded with others; from which it may be distinguished by its size, which is from nne and half to two inches in length, by its undulated form, and by its colour; being of a pale red, and yellow, in broad, faint, irregular stripes: much resembling an outer layer of the coats of an onion; whence the name. It is not uncommon, on rocks or the carapace of Crustaceans.

* A. SQUAmula. Turt. Lin. Pen. Brit. Zo., vol. 4, p. 109. Mont. 'Test. Brit., vol. 1, p. 156. Flem. Brit. An., p. 324. Common, attached to every kind of sub. stance. Montagu was inclined to suppose that this might be the same as the two last named species in their early state (vol. 2, p. 581), founding his remark chiefly on the difficulty of distinguishing them, and indeed the remaining kinds, when young. It must be admitted that at this stage the distinction is not always easy; but their appearance is very different when fully grown.

* A. UNdulatA. Mont. T'est. Brit., vol. 1, p. 156, pl. 4, fig. 6. Flem. Brit. An., p. 395 :-who supposses Ostrea Striata of Montagu to be the same species. Com!mon, though scarcely abundant.

* A, ACULEATA. 'Turt. Lin. Mont. Test. Brit., vol. 1, p. 157, pl. 4, fig. 5 . Attached to sea-weeds.

* A. PUNCTATa. Flem. Brit. An., p. 395. Common.

* A. CYlindricA. Flem. Brit. An., p. 395. Common.

A. INFLATA. Nobis. This, which I suppose to be undescribed, is a minute species, the diameter of tho dis's being about the tenth of an inch. The form is circular, the valves smooth and regular; but it is especially characterized by the elevation of its centre; which is almost 
as high as the diameter of the valve. From this the beak is bont down, and sinall. The specimen described, which was attached to the shell of a pinna, has the summit inflated and round; but a specimen which I found in Mount's bay attached to sea-weed, was about equally elevated but pointed. Further research will decide whether these specimens belong to the same species. In another specimen, found with the former in Mount's bay, the beak approached but did not join the margin; and the upper valve was characterized by a number of well marked circular raised ribs.

\section{BRACHIOPODA.}

The shell bivalve, adhering either directly or by a tendinous cord.

\section{TEREBRATULA.}

GENERIC CHARACTER: Shell with valres unequal, regular, subtriangular, attached to bodies by a short tendinous pedicle; beak of the larger valve produced, often curved, perforated at the summit; hinge with two teeth; two nearly bony, slender, elevated, forked, variously branched processes rise from the disk of the small valre, and support the animal.

I found the toothed valve of what I believe a species of this genus, at Par: but the precise species is uncertain.

CLASS IV.

MOLLUSCA.

The body sometimes naked, either destitute of any solid internal parts, or inclosing a shell or other hard substance, and sometimes provided externally with a shell covering or sheathing, but never composed of two opposite valves united by a hinge.

The distinguishing character of the Mollusca is, that they have no vertebræ, are wholly without articulations, and have a more or less prominent head at the anterior part of the body. Their instincts are more developed than any of the species already enumerated.

\section{PHYLLIDIANA.}

Some have no shell, either within or without; others are wholly or in part covered by a shell, sometimes composed of one single piece, sometimes of a range of moveable and distinct pieces.

CHITON.

GENERIC CHARACTER: Shell formed of separate pieces, in number from eight to six, fastened together 
at the edges and forming a dorsal covering; the mantle by which they are kept together, allowing of motion, and forming a border round the whole.

* C. FASCICULARIS. Turt. Lin. Mont. Test. Brit., vol. 1, p. 5. Flem. Brit. An., p. 288. Not uncommon, sheltered under stones, or at the roots of the smaller sea-weeds and Corallines. When separate from its resting place, in rolls itself up into a ball; as is the habit also of the other Chitons.

C. CRINITUS. Turt. Lin. Pen. Brit Zo., vol. 4, pl. 36, fig. 1. Mont. Test. Brit., vol. 1, p. 4. Scarce; but $\mathbf{I}$ have found it at Coomb in Lantivet bay, among the roots of sea-weeds.

* C, MARginates. Turt. Lin. Pen. Brit. Zo., vol. 4, pl. 36, fig. 2, Mont. Test. Brit., vol. 1, p. 1. Flem. Brit. An., p. 289. Not uncommon.

* C. RUBER. C. Levis. Turt. Lin. Pen. Brit. Zo,, vol. 4. pl. 36, fig. 3. Mont. Test. Brit., vol. 1, p. 2. C. R. Flem. Brit. An., p. 289. It is to be observed, that these animals are subject to variation of colour; so that scarcely two specimens of any of the species will be found exactly similar in this respect.

- C. CINEREUS. Turt. Lin. Mont. Test. Brit., vol. 1, p. 3. Flem. Brit. An., p. 289. Not uncommon:

- C. AlbUS. Turt. Lin. Mont. Test. Brit., vol. 1, p. 4. Flem. Brit. An., p. 290. Common, on shells or stones from deep water.

PATELLA.

GENERIC CHARACTER: Shell univalve, flattened co. nical or like a shield, concave and simple below, without fissure on the margin; the summit entire, inclining forward.

* P. VULGATA. Turt. Lin. Pen. Brit. Zo., vol. 4, pl. 89, fig. 145. Mont. Test. Brit., vol. 2, p. 475. Flem. Brit. An. p. 286. Limpet. A bundant, most so on the east side of the county. They are employed to feed Ducks.

* P. DEPRESSA. Turt. Lin. Pen. Brit. Zo., vol. 4, pl. 89, fig. 146. Mont. Test. Brit., vol. 2, p. 475. Borlase's Nat. Hist. of Corn., pl. 28, fig. 3. It remains uncertain whether this be a variety of $\mathbf{P}$. Vulgata, or a separate species: Montagu and Fleming inclining to the former, Pennant and Turton to the latter opinion.

* P. INTORTA. Flem. Brit. An., p. 287. A specimen which with doubt, I have assigned to this species, was found near Seaton, east of Looe. It is seven-tenths of an inch in its longest diameter and about six-tenths in beight, smooth, conical, the summit not inclined, bearing resemblance to Pennant's firure of P. (Emarginula) Fissura, but 
without the slit. The shell was well worn, and therefore probably destitute of marks which in a living state, may characterize it; but it differs so far from Pennant's figure of $\mathbf{P}$. Intorta, pl. 90, fig 148, as to leave no doubt of its being distinct.

* P PELLUCIDA. Turt, Lin. Pen. Brit. Zo, vol. 4, pl. 90, fig. 150. Mont. Test. Brit., vol. 2, p. 477. Flem. Brit. An. p. 286. Common, but in its different stages of growth so various, as to have led to confusion of the synonyms. Montagu confounded it with $\mathbf{P}$. Intorta, a species which it appears, at that time he had not seen.

* P, LEVIS. Pen. Brit. Zo, vol. 4, pl. 90, fig. 151. Flem. Brit. An., p. 28\%. Common, on the fronds of the larger sea-weeds.

* P. VIRGINEA. P. Parva. Turt. Lin. Mont. Test. Brit., vol. 2, p. 480. P. V. Flem. Brit. An., p. $28 \%$. Common, on rocks near low-water inark.

P. CLEALANDI. Flem. Brit. An., p. 287. Length about thre tenths of an inch, and not quite so wide: the form an irregular cone, the summit elevated, pointed, rather on one side. The edge even, without longitudinal ribs, but with concentric lines of growts. Colour dull white. A single specimen found at Gorran.

P. BIMACULATA. Mont. Test. Brit., vol. 2, p. 482, pl. 13, fig. 8. "An opaque oval shell, of a glossy yellow colour, and perfectly smooth, with only the rudiment of a vertex at the smaller end, marked by a transverse, oblong, black spot; another oblong spot of the same colour near the other end, placed longitudinally; the shell is convex, but not much elevated. Inside concave, smooth, glossy, yellow; margin thin. Length a quarter of an inch, breadth rather more than one-eighth; height about one sixteenth of an inch. We found one of this rare and singular species at Falmouth in Cornwall; and another, in every respect the same at Milton sands, on the south coast of Devon; they were both recent and perfect shells, but not alive." Such is Montagu's account of this obscure species. I have met with a single specimen of what perhaps may be the same species: length five twentieths of an inch, breadth three twentieths; oval, regular, the umbo about the middle of the length and breadth; form depressed. The texture somewhat flexible; margin even, but a little waved, not in its substance, but monlded by the shell to which it was attached. Colour reddish yellow. It was fixed on the shell of a pinna, after the manner of Pileopsis Hungaricus, and like that shell seems not to be accustomed to change its place.

The form and habits of the shell here described seem to intimate an affinity to the genus Umbrella: (characterized as 
orbicular, subirregular, nearly flat, slightly convex above, with a small apex near the middle; margin acute; inner surface rather concave, with a callous disk, depressed in the centre, with a smooth border) all the recognized species of which are Indian.

\section{CALYPTRICIANA.}

Shell always exterual, covering the animal.

EMARGINULA.

GENERIC CHARACTER: Shell shieldike, conical, vertex inclined, cavity simple, the hinder margin notched.

* E. FISSURA. Patella F. Turt. Lin. Pen. Brit. Zo., vol. 4, pl. 90, erroneously marked 151. Mont. Test. Brit., vol. 1, p. 490, E. F. Flem. Brit. An, p. 565. Not uncommon, from deep water.

FISSURELLA.

GENERIC CHARACTER: Shell shield-like or depressed conical, concave below; without a spire, and perforated at the top; aperture oblong.

* F. GR AECA. Patella G. Turt. Lin. Pen. Brit. Zo., vol. 4, pl. 89, fig. 153. Mont. Test. Brit., vol. 2. p. 492. F. G. Flem. Brit. An., p. 364. Rare. I have obtained it from near Looe, at Falmouth, and near the Land's-end but not with the animal. Mr. Forbes (Fauna Monensis) says that their habit is, to attach themselves to Pectens, in deep-water.

F. APERTURA. Patella Fissurella. Turt. Lin. P. A pertura Mont. Test. Brit., vol. 2, p. 492, pl. 13, fig. 10. Flem. Brit. An., p. 364. Very rare.

* F. NUBECULA. Flem. Brit. An., p. 365, from Dr. Turton; who obtained it near the Land's-end; from whence also I procured a few specimens. It has been found at Gorran by Mr. Peach.

\section{PILEOPSIS.}

GENERIC CHARACTER: Shell obliquely conical, curved forward; the top bent, approaching to a spiral; aperture somewhat oval; anterior margin shortest, acute, ending in a slight sinus; hinder margin larger, round; a lengthened, arched, transverse muscular impression under the hinder border.

- P. Hungaricus. Patella H. Turt. Lin. Pen. Brit. Zo., vol. 4, pl. 90, fig. 147. Borlase's Nat. Hist. Corn., pl. 28, fig. 4. P. Ungarica. Mont. Test. Brit., vol. 2, p. 486. Capulus H. Flem. Brit. An., p. 363. Not uncommon on the Pinna from deep water; and one specimen of unusual size liad its border so curved to accommodate itself to the irregularity of the surtace, as to show that it 
had not changed its situation, from an early stage of growth. I have also obtained it, of small size, from the stomach of a fish.

* P. MILITARIS. Patella M. Mont. Test. Brit., vol. 2, p. 488, pl. 13, fig. 11. Capulus M. Flem. Brit. An. p. 364. At various parts of the coast, but scarce.

P. ANTIQUATUS? Montagu describes this shell (Patella Antiquata) as liable to great variation; under which it is not improbable that more than one species is included. My specimen, which was attached to a Pinna, was about a line in its longest diameter; texture thin, and in parts nearly transparent: longitudinal lines from the point to the margin simple, causing the edge to be angular; crossed in their progress by circular ridges, seven in number, inclined towards the margin. Curve of the cap to the right, as the broad expanse is placed forward: its form much as in $\mathbf{P}$. Hungarica, but more bent down. Colour pale yellow.

\section{CALYPTRAEA.}

GENERIC CHARACTER: The shell conoidal, summit erect, imperforate, subacute. Cavity furnished with an attached, convolute plate.

C. SINENSIS. Patella S, Turt. Lin. P. Chinensis. Mont. 'Test. Brit., vol. 2, p. 489, pl. 13, fig. 4. C. Ch. Flem. Brit. An., p. 362. Found on oysters at Helford, and generally wherever native oysters are dredged; but soon falling off spontaneously, it escapes observation.

\section{ANCYLUS.}

GENERIC CHARACTER: The shell ovate, conical, simple, the tip central, posterior, rather obliquely recurved to the right; cavity with a lunate submarginal scar, interrupted on the left side. This genus is by Gray, classed with the Limnaada, on account of the form of the animal inhabitant. The shell, continues Mr. Gray, from whom the generic character is derived, differs from Siphonaria, with which alone it can be confounded, on account of the peculiar form of the muscular scar, and the lateral situation of the apex; in being thin and pellucid; only finely striated and covered with a thin olive periostraca. It only agrees with Patella in the outward appearance of the shell, for in that genus the apex is anterior, and in this it is posterior, as in most univalves.

* A. FLUVIATILIS, Patella F. Mont. Test. Brit, vol. 2, p. 482. Flem. Brit. An., p. 280. Gray's Turton's Manual, p. 249 , pl. 10, fig. 125 . Common on stones, in rivulets.

\section{$B U L L A E A N A$.}

Either without a shell; or the shell without columella, or projecting spire; inflated; aperture large, the length of the shell. 
BULLAEA.

GENERIC CHA RACTER: The shell thin, partially rolled and spiral on one side; without columella or spire; aperture large, dilated at the upper part.

B. APERTA. Bulla A. Turt. Lin. Mont. Test. Brit., vol. 1, p. 208, pl. vignette, 2 part, fig. 1. Flem. Brit. An., p. 294. Rare. I have met with a specimen much jesembling Montagu's account of this shell, but differing sufficiently to require mention; chiefly at the junction of the pillar with the expansion, where the whorl is twisted, and tapers up to join the wing. Length six twentieths of an inch, a little more than four twentieths of an inch wide; white, and slightly transparent.

\section{BULLA.}

GENERIC CHARACTER: The shell oval, globular, convolute; no columella, or projecting spire, or only sligbtly elevated; aperture the length of the shell, outer nargin sharp.

Bulla differs from Bullæa, by the shell being cornpletely convolute, always visible externally, which the latter is not; and only partially covered by the hinder part of the animal.

* B. LIGNARIA. Turt. Lin. Pen. Brit. Zo., vol. 4, pl. 70, fig. 83. Borlase's Nat. Hist. Corn., pl. 28, fig. 14 . Mont. 'Test. Brit., vol. 1, p. 235. Flem. Brit. An., p. 292. Not uncommon, chiefly in trawls.

B. AMPULla. Mont. Test. Brit., vol. 1, p. 206, pl. 7, fig. 1. Flem. Brit. An., p. 292. Montagu found two or three of what he believed to be this species, in sand from Falınouth harbour.

B. UMBILICATA. Mont. Test. Brit., vol. 1, p. 222, pl. 7, fig. 4. Flem. Brit. An., p. 293. Found by Montagu sparingly, amongst sand from $\mathbb{P}$ almouth harbour.

- B. CYLindraceA. Pen. Brit. Zo., vol. 4, pl.70, fig. 85. Mont 'Test. Brit., vol. 1, p. 221, pl. 7, fig, 2. Flem. Brit., An., p. 293. Found by Montagu at Falmouth, and I have obtained it from the byssus of a Pinna.

B. TRUNCATA, Turt. Lin. Mont. Test. Brit., vol. 1, p. 223, pl. 7, fig, 5. Flem. Brit. An., p. 293. Found by Montagu, not uncommon in sand at Falmouth.

B. PATÚl, Pen. Brit. Zo., vol.4, pl.70, fig. 85. A. Mont. Test. Brit., vol. 1, p. 207. I have obtained it from the depth of 40 fathoms, on a branch of Gorgonia Verrucosa.

\section{COLIMACEA}

The shell spiral, with no other projecting part on the outer surface, than the lines of growth; the right margin of the aperture often recurved, or reflected outwards. 


\section{HELIX.}

GENERIC CIIARACTER: The shell orbicular, convex or conoidal; sometimes globular, the spire rather elevated; aperture entire, transverse, very oblique, contiguous to the axis of the shell; the margins disunited by the projection of the penultimate whorl.

Helix is distinguished from Pupa by the general form of the shell, which is never cylindrical, and by the borders of the aperture being disunited; from Bulimus by the aperture being rather transverse than longitudinal, and its plane very oblique, and almost perpendicular to the axis of the spire; and from Planorbis by the left margin of the aperture being contiguous to the axis of the shell, whereas in that genus it is very remote from it. The right margin, in the adult Helix, is reflected outwards, contrary to what occurs in aquatic shells. Helix is readily known by the projection of the penultimate whorl into the aperture. Journal of Science, vol. 15, p. 237.

Mr. Gray denominates the family Helicidx, and characterizes the genus Helix: shell globose or depressed; mouth semilunar; peristome rather thickened and reflected.

* H. Aspersa. H. Hortensis. Turt. Lin. Pen. Brit. Zo., vol. 4, pl. 84, fig. 129. H. A. Mont. Test. Brit., vol. 2, p. 40\%. Flem. Brit. An., p. 263. Gray's Turt., p. 128, pl. 4, fig. 35. Snail. Common.

* H. HORTENSIS. Mont. Test. Brit., vol. 2, p. 412. Flem. Brit. An., p. 264. Gray's Turt., p. 130, pl. 3, fig. 24. Common.

* H. NEMORALIS. Pen. Brit. Zo., vol. 4, p. 137. Stew. Elem., vol. 2, p. 414. Nont. Test. Brit., vol. 2, p. 411. Flem. Brit. An., p. 264. Gray'a Turt., p. 132, pl. 3, fig. 23. Common.

- H. PISANA. H. Zonaria. Pen. Brit. Zo., vol. 4, pl. 85, fig. 133. H. Cingenda. Mont. Test. Brit., vol. 2, p. 418. H. P. Fem. Brit. An., p. 259. Gray's Turt., p. 158, pl. 4, fig. 30. The only place in the west of England in which this shell is found, is at St. Ires, chiefly about the promontory north of the town; where it exists in profusion. A sandy soil is perhaps necessary to its existence.

* H. RUFESCENS. Mont. Test. Brit., vol. 2, p. 420. Flem. Brit. An., p. 261. Gray's Turt., p. 156, pl. 3, fig. 23. Common.

* H. HISPIDA. Mont. Test. Brit., vol. 2, p. 423, Flem. Brit. An., p. 261. Gray's Turt., p. 154, pl, 4, fig. 41. This species seems to be thinly scattered. Montagu found it in some plenty near Penryn; and I have obtained it in my own neighbourhood. 
* H. GRANUlat TA. Gray's Turt, p. 151, pl. 3, fig. 29. Not uncommon. It has been confounded with the last.

* II. CONCINNA. Gray's Turt., p. I54, pl. 12, fig. 135. Common.

H DEPILATA. Gray's Turt., p. 155, pl. 2, fig. 135.* Not uncommon.

* H. VIR GATA. Mont. Test. Brit,, vol, 2, p. 415. Flem. Brit. An., p. 261. Gray's 'Turt., p. 160, pl. 4, fig. 31. Common and sometimes in profusion, on grass and bushes near the sea. It is most usually found on a sandy soil; and in situations characterized by plenty of sand, it appears earlier in the year, in others searcely before July. Must of the banded Helicidæe have similar habits.

H. CAPERATA. Mont. Test. Brit., vol. 2, p. 430.pl. 11, fig. 11. Flem. Brit. An., p. 262. Gray's Turt, p. 162, pl. 4, fig. 32. Local, Montagu seems to have observed it in Cornwall; as I suppose I have also done.

* H. ERICETORUM. Turt. Lin. Mont. Test. Brit., vol. 2, p. 437. H. Albella. Pen. Brit. Zo., vol. 4, pl. 35, fig. 122. H. E. Gray's Turt., p. 163, pl. 4, flg. 37 . Common in sandy districts, especially near the Lands-end and St. Ives.

H. FUSCA. Mont. Test. Brit. vol. 2, p. 424, pl. 13, fig. 1. Flem. Brit. An., p. 264. Gray's Turt., p. 147, pl. 4, fig. 36. This shell is distinguished by the circumstance, noticed by Montagn, that its substance is so thin and Mexible as, when the animal dies, to contract with it into depressions. I have found a few specimens which were as thin and flexible as tissue paper.

II. REVELATA. Gray's Turt., p. 152, pl. 11, fig. 133. H. Subvirescens. Bellamy's Nat. Hist. South Devon, p. $4.18, \mathrm{pl}$. 18. Mr. Bellamy discovered this species near Mevagissey, and it has been since found by Mr. Forbes in Guernsey. Mr. Bellamy's original specimen was examined by the eminent naturalists present at the meeting of the British association at Plymouth in 1841; and especially by Mr. Gray.

\section{VITRINA.}

GENERIC CHARACTER: Shell imperforated; spire depressed, of only a few whorls; mouth large, rounded, lunate; peristome thin.

V. PELLUCIDA. Gray's Turt., p. 120, pl. 3, fig. 21. Scarce.

\section{ZONITES.}

GENERIC CHARACTER: The shell depressed, hemispherical, thin, with a flattish spire, and a large lunate mouth, with thin simple lips, that are neither thickened nor reflexed. 
This genus, which seems perfectly natural, is adopted by Mr. Gray from Mountfort; and is to be regaried as an amendment of the system of Lamark.

Z. ROTUNDATUS. Helix Radiata. Mont. 'Test. Brit., vol. 2, p. 432. H. Rotundata. Flem. Rrit. An., p. 263. Z. R. Gray's Turt. p. 165, pl. 5, fig. 44. Common.

Z. CELlariUS. H. Nitens. Turt. Lin. H. Lucida. Mont. Test. Brit., vol. 2, p. 425. Z. C. Gray's Turt., p. 170, pl. 4, fig. 40 .

Montagu gives the following account of what he supposes to have been a variety of this species. Those found at Newbury on peat were dark, and never exceed a quarter of an inch in breadth. "That found under water was crawling upon Brooklime, and was considerably larger; it was in a water course, or drain to a swamp, near Penzance in Cornwall. These however appear from their shape to be the same, but whether they are really distinct from the Lucida (Z. C.) or only varieties, the observations of future Conchologists must determine. We do not recollect whether the animal we found under water was of the true aquatic kind, or whetber it possessed four retractile tentacula, and had by accident fallen into that element; but we never before or since, found one so large, so extremely thin and pellucid, or of so light a colour.

* Z. CRYSTALLINUS. Gray's Turt., p. 176, pl. 4, fig. 42. Not coinmon.

Z. ALLIARIUS. Gray's Turt., p. 168, pl. 4, fig. 39. Scarcely common.

\section{SUCCINEA.}

GENERIC CHARACTER: The shell oval, oblong, thin, with a short conical spire and rapidly enlarging whorls ending in a large, longitudinal, oblique mouth, with the peristome disunited behind ; pillar smooth, with an imperforated axis.

The genus is known from Helix and Znnites by its oblong shape, and from Limnæus by there being no mark of an oblique fold on the pillar.

* S. PFEIFFERI. Gray's Turt. p. 178, pl. 6, fig. 74. Scarcely rare. I found some specimens in a small dripping stream, among multitudes of Limnæus Pereger.

S. PUTRIS. Helix. P. Turt. Lin. Mont. Test. Brit., vol. 2, p. 376. S. P. Flem. Brit. An., p. 276. Gray's Turt., p. 178, pl. 6, fig. 73. I entertain little doubt of its being Cornish, but $I$ do not find it within the sphere of my research.

\section{BULIMUS.}

GENERIC CHARACTER: The shell oblong or turreted, the spire ending rather acutely, with the last rolution larger 
than the next; aperture oval, entire at the base, not half as long as the spire, and without tecth; the peristome interrupted; outer lip generally thickened and reflexed.

The shell of this genus is distinguished from that of Limnaus by wanting the oblique fold on the pillar; from Clausilia, in being regular, and in having the peristome simple and interrupted; and from Pupa in having the spire regularly tapering.

* B. ACUTUS. Turbo Fasciatus. Turt. Lin. Pen. Brit. Zo., vol, 4, pl. 82, fig, 119. Stew. Elem., vol. 2, p. 410. Mont. Test. Brit., vol. 2, p. 346. B. A. Flem. Br. An., p. 265. Gray's 'Turt., p. 184, pl. 6, fig. 17. Abundant in the heat of summer, in some situations near the sea; and remarkably so in the west of the county, in sandy soil. This shell is sometimes carried into the sea to a considerable distance. I have taken it from the stomach of a Dab (Pleuronectes Limanda) that had swallowed it, in company with other small shells, for the sake of the Hermit Crab that occupied it. I have also found it mixed with shellsand from the Isle of Sark.

B. OBSCURUS. Helix O. Mont. Test. Brit., vol. 2, p. 391. Flem. Br. An., p. 265. Gray's Turt., p. 183, pl. 6, fig. 63. Not common.

\section{ZUA.}

GENERIC CHARACTER: The shell ovate, subcylindrical, somewhat blunt, with a smooth polished periostraca; mouth ovate, thickened and united all round; peristome toothless; axis imperforated.

* Z. LUBRICA. Helix L. Turt. Lin. Mont. 'lest. Brit., vol. 2. p. 390. Bulimus L. Flem. Brit. An., p. 265. Z. L. Gray's Turt., p. 188, pl. 6, fig. 65. Common.

\section{PUPA.}

GENERIC CHARACTER: The shell cylindrical, abruptly obtuse; whorls close pressed, gradually enlarging; mouth semi-oval, mostly toothed inwardly; peristome reflexed, and interrupted behind.

* P. UMBllicatA. Turbo Muscorun. Turt. Lin. Mont. Test. Brit., vol. 2, p. 335. Flem. Brit. An., p. 268. P. U. Gray's Turt. p. 194, pl. 7, fig. 78. Common.

VERTIGO.

GENERIC CHARACTER: The shell subcylindrical, abruptly obtuse, the whorls close pressed, gradually enlarging; mouth contracted, more or less angular, generally toothed inwardly, and thickened by an exterior rib; peristome simple. This genus has been separated from that of Pupa, because the animal has only the upper pair of tentacles, which bear the eyes, dereloped. 
*V. EDENTULA. Gray's Turt., p. 199, pl. 7, fig. 80. Locally common.

V. PYGMEA. Turbo Sexdentatus, Junior. Mont. Test. Brit., rol. 2, p. 337, pl. 12, fig. 8. V. P. Gray's Turt., p. 202, pl. 7, fig. 83. Montagu found it in a boggy place in Cornwall, on the yellow water flag; and I believe I found it in a pond at Pentuan.

\section{BALEA.}

GENERIC CHARACTER: The shell reversed, thin, with a lengthened, taper spire, the last volution larger than the next, aperture roundish oval, entire at the base, oblique, with a single tooth on the pillar, which is wanting in the young shells, and the pillar is destitute of any valvelike plait or clausium. From Bulimus and Pupa this genus is distinguished by the aperture being left handed; from Clausilia in having the ultimate volution proportionately larger than the next; and from Vertigo, in the regularity of its mouth. From the young of Clausilia it may be known by the front of the last whorl being convex and simple, not flattened and furnished with a keeled ridge near the nuter edige. Gray.

* B. PERVERSA. Turbo P. Mont. Test. Brit, vol, 2, p. 355. pl. 11, fig. 12. B. P. Flem. Brit. An., p. 271. Gray's I'urt., p. 207, pl. 6, fig. 70. Common.

\section{CLAUSILIA.}

GENERIC CHARACTER: The shell reversed, with a lengthened, slender, spindle formed spire, the last volution less tumid than the one before it, with an obtuse or papillary summit; aperture oval, oblique, united all round and margined, toothed; throat with an internal spiral shelly plait (clausium) fixed on an elastic pedicle, which closes the cavity when the animal is withdrawn.

* C. BIPLICATA. Turbo B. Mont. Test. Brit., vol. 2, p. 361, pl. 11, fig. 5. C. B. Flem. Brit. An., p. 271. Gray's Turt., p. 214, pl. 5, fig. 55. Common.

C. NIGRICANS. Turbo Bidens. Turt. Lin. T. Perversus. Pen. Brit. Zo., vol. 4, pl. 82, fig. 116. T. B. Mont. Test. Brit., vol, 2, p. 35\%, pl. 11, fig. 7. C. Perversa. Flem. Brit. An., p. 27I. C. N. Gray's Turt., p. 217, pl. 5, fig. 58. Not common within my observation.

\section{AURICULIDAE.}

Is a family instituted by Mr. Gray, and chiefly characterized by peculiarities in the animal: "which has an elongated foot, an elongate ringed muzzle, two subcylindrical tentacles with the eyes near the inner side (that is, placed behind instead of in front of) their base; body spiral, placed 
on the centre of the foot, and covered with a thin mantie, with a thickened edge, which is itself covered with an external spiral shell, which has a plaited pillar in all its ages."

\section{CARYCHIUM.}

GENERIC CHARACTER: The shell spiral, thin, conic orate; mouth oblong, longitudinal, two or three toothed, compressed, rather oblique, rounder at each end; peristome interrupted, thickened, and rather reflexed.

C. MINIMUM, Helix Carychium. Turt. Lin. Turbo C. Mont. Test. Brit, vol. 2, p. 339. C. M. Flem. Brit. An., p. 271. Gray's Turt., p. 221, fig. , p. 219. Not uncommon.

\section{CYCLOSTOMA.}

GENERIC CHARACTER: Shape of the shell variable; whorls of the spire cylindrical; aperture round, regular; the margins circularly united, or reflected by age. An operculum.

Mr. Gray constituted this a family under the name of Cyclostomidæ. His generic character of Cyclostoma is: shell ovate, spiral; mouth simple, united all round; operculum of a few flat whorls, with a simple shelly internal coat: the foot divided into two parts by a longitudinal central groove.

C. ELEGANS. Turbo Tumidus. Turt. Lin. Pen. Brit. Zo., vol. 4, pl. 82, fig. 110, T. Elegans. Mont. Test. Brit., vol. 2, p. 342. C. E. Flem. Brit. An., p. $25 \%$. Gray's Turt., p. 275, and fig. 1, 2, 3, p. 273, and pl.7, fig. 75. I have only obtained a specimen, by gift, from the west of the county.

\section{LIMNBEANA.}

The shell spiral, the outer surface mostly smooth; right margin of the aperture acute, and not reflected.

Mr. Gray denominates the family Limnæadæ; and observes that the forms of the shells vary much in different genera, "in shape and form;" but the group is natural, from the similarity of the animals.

\section{LIMN FUS.}

GENERIC CHARACTER: The shell ovate, thin, dextral, transparent, spiral; mouth ovate, with a single, oblique plait on the middle of the column, running into the axis: Gray; who observes, this geuns is known from Amphipeplea and Physa by the inner lip not being extended over the body whorl of the shell; and from Aplexus by the shell being dextral and having the pillar plait.

* L. PEREger. Helix Peregra. Turt. Lin. H. Putris. Pen. Brit. Zo., vol. 4, pl. 86, fig. 137. H. P. Mont. 'Test. 
Brit., val. 2, p. 373, pl. 16, fig. 3. L. Limosa. Flen. Brit. An., p. 275. L. P. Gray's Turt., p. 233, pl. 9, fig. 101. Common.

L. PALUSTRIS. Helix P. Turt. Lin. H. Stagnalis, var. Pen. Brit. Zo., vol. 4, pl. 86. fig. 136. B. H. P. Mont. Test. Brit., vol. 2, p. 370, pl. 16, fig. 10. Flem. Brit. An., p. 274. Gray's Turt, p. 239, pl. 9, fig. 107. Not cominon.

* TRUNCATUlus. Helix Fossaria. Mont. Test. Brit., vol. 2, p. 372, pl. 16, fig. 9. L. F. Flem. Brit. An., p. 274. L. T. Gray's Turt., p. 240, pl. 9, fig. 108. Irregularly distributed. Montagu found it "upon the top of one of the highest hills in Cornwall, at the verge of a spring near the Lizard, where no other species of shell was to be found".

L. GLABER. Helix Octona. Pen. Brit. Zo., vol. 4, pl. 86, fig. 135. H. Octanfracta. Mont. Test. Brit., vol. 2, p. 396, pl. 11, fig. 8. L. Octona. Flem. Brit. An., p. 274. L. G. Gray's Turt., p. 242, pl. 9, fig. 106. The indefatigable Montagu says, "we have found it only in one part of England, a splashy place by the road side (a muddy pool by the side of the high road on the top of a hill) half way between Fowey and Looe in Cornwall, where they were plentiful in all stages of growth; the y oung are less slender, and have only live or six volutions." Such however have been the changes effected within the space of forty years, that I have hitherto failed in discovering these shells.

\section{PLANORBIS.}

GENERIC CHARACTER: The shell discoidal, spire depressed, and all the whorls appearing above and beneath; aperture oblong, lunate, distant from the axis; cavity simple; margin not reflexed.

P. MARGINATUS. Helix Complanata. Turt. Lin. H. Planorbis. Pen. Brit. Zo., vol. 4, pl. 83, fig. 123. Borlase's Nat. Hist. of Corn., pl. 23, fig. 8. H. C. Mont. Test. Brit., vol. 2, p. 450. P. C. Flem. Brit. An., p. 278. P. M. Gray's Turt., p. 265, pl. 8, fig. 8\%. Introduced on the authority of Borlase.

\section{NERITACEA.}

The shell, of the river or sea, flattened oval, withont Columella; left margin of the aperture resembling a half partition.

NERITA.

GENERIC CHARACTER: Shell semiglobular or oval, flattened below; and without an umbilicus. Aperture semicircular; the left margin flat, acute; without denta- 
tions on the inner face of the right margin. Operculum with a projecting tooth,

* N. LITTORALIS. Turt. Lin. Pen. Brit. Zo., vol. 4, pl. 87, fig. 143. Mont. Test. Brit., vol. 2, p. 467. Stew. Elem., vol. 2, p. 417. Flem. Brit. An., p. 318. Abundant. The Turbo Neritoides, as marked in the collection of the Museum, from the Mediterranean, is too clearly like a variety of this shell with alternate broad stripes of yellow and brown in the direction of the whorls crossed by zigzag markings of the same, to admit of a doubt as to their identity with those found on our shores; but in the shell at least, there is not sufficient grounds for considering thern as forming a distinct species.

\section{NATICA.}

GENERIC CHARACTER: The shell subglobular, umbilicated; aperture entire, semicircular; left lip oblique, not toothed, callous; the callosity modifying the umbilicus, and sometimes covering it; right lip acute, always smooth insile. An operculum.

* N. GLAUCina. Nerita G. Turt. Lin. Pen. Brit. Zo., vol. 4, pl. 87, fig. 141. Mont. Test. Brit., vol. 2. p. 469. Stew. Elem., vol. 2, p. 417. Natica G. Flem. Brit. An., p. 319. N. Monilifera. Forbes, Fauna Monensis, p. 29. Common of small size; but I have never seen it so large any where else as at Par.

N. ALDERI. Forbes, Fauna Monensis, p. 31. This species has been lately discovered, as distinguished from the last, with the young of which it has been confounded. Two specimens were procured from near the Land's-end. N. NITIDA. Flem. Brit. An., p. 319. A single specimen was obtained from near the Land's-end. For the two last named species, as well as several other of the smialler species of Cornish shells, I am indebted to the kindness of Mr. Willianı Curnow, Gardener, of Newlyn; who has collected them with persevering industry.

* N. PALLidULA. Nerita P. Turt. Lin. Mont. Test. Brit., vol. 2, p. 468. Stew, Elem., vol. 2, p. 418. Flem. Brit. An., p. 320. Not common. I found a specimen at T'alland sand.

* N. LACUNA. Helix L. Mont. Test. Brit., vol. 2, p. 428, pl. 13, fig. 6 . Natica L. Flem. Brit. Av, p. 320. Scarcely common.

\section{IANTHINEA.}

The shell inflated, conoidal, thin; aperture triangular. Columella straight, projecting beyond the base of the right lip; which has a sinus in the middle. No operculum. 
IANTHINA.

GENERIC CHARACTER: The shell inflated, conoidal, thin, transparent; aperture triangular; columella straight, passing beyond the base of the right lip.

* I. COMMUNIs. Helix Ianthina. Turt. Lin. J. C. Flem. Brit. An., p. 326. Crouch's Intro., pl. 16, fig. 3. 'The species has been found on several parts of our north and south coast; I found it myself at St. Ives, and I possess two or three specimens that came on shore not far from my own residence. Their occurrence however, is altogether casual, and depends on a combination of wind and weather. The usual season is from July to November, when the wind is rough or long between west or south; under which circumstances several floating animals, as Physalia, Velella, with the Ianthinæ, are driven on our coast from the Atlantic, sometimes in considerable numbers. This shell, however, is so brittle, as scarcely to bear the touch of land; and in consequence, vigilance must be joined with good fortune, to obtain sound specimens.

I. EXIGUA. Turton, Mag. Nat. Hist.. vol. 7, p. 352.

Turton says. "In the small coves about the Land's-end, in Cornwall, the Ianthina Fragilis (Communis) is occasionally wafted, by a gentle south west wind, in prodigious fleets; all alive, and born up upon the water by their clusters of tough bubble like vesicles. By the retreating waves, most of them are carried back into the ocean; so that it requires a fortunate combination of tide, wind, and wave, to see them in all their splendour. This most happens about the months of July and August. The fishermen's wives call them Bullhorns, which supposes a prior knowledge of their appearance. Among them are sometimes found a few of I. Exigua, which having been probably regarded as the young of I. Fragilis, may have caused them to be overlooked." "In the contributions towards a History of $\mathbf{S}$ wansea, by $\mathbf{L}$. W. Dillwyn, Esq.," it is observed. "1824, July. Many thousand shells of Ianthina, of which some retained the animal alive; and skeletons of the Medusa Velella and of Medusa Navicula, were thrown on the shores of $\mathrm{Oxwich-bay;} \mathrm{the} \mathrm{weather} \mathrm{was}$ remarkably hot at the time. A few of these Ianthina, which had before at different times been washed up in the same bay, received from Dr. Leach his M.S. name of I. Rotundata; and Mr. Jeffreys informs me, that among the multitude which now covered the shore, he detected a few shells of I. Mediterranea mixed with them."

\section{MACROSTOMIANA.}

The shell earshaped, aperture mnch dilated, margins dis. united, no columella or operculum. 


\section{SIGARETUS.}

GENERIC CHARACTER: The shell earshaped, nearly orbicular; left lip short and spiral; aperture entire, much dilated, rounded, oblong; margins not united.

* S. PERSPICUUS. Bulla Haliotoidea. Mont. Test. Brit., vol 2, p. 211. pl. 7, fig. 6. S. Haliotoideus. Flem. Brit. An., p. 360. S. P. Forbes, Fauna Monensis, p. 29. Obtained from near the Land's-end.

\section{PLICACEA.}

Aperture of the shell not effuse; columella plaited.

TORNATELLA.

GENERIC CHARACTER: The shell convolute, ovate cylindrical, mostly striated transversely; no epidermis; aperture oblong, entire, the right lip sharp; one or more plaits on the columella.

T. TORNATILIS. Voluta T. Turt. Lin. Pen. Brit. Zo., vol. 4, pl. 71, fig. 86. T. T. Flem. Brit. An., p. 336. I have only seen two specimens; which were procured from the west of the County.

T. DENTICULATA. Voluta D. Mont. Test. Brit., vol. 1, p. 234. Actæon D. Flem. Brit. An., p. 33\%. A specimen from the Land's end.

\section{SCALARIANA.}

Without plaits on the columella; margins of the aperture circularly united. Shells of this family have a tendency to form a loose spire, so that the whorls are often disunited and do not rest on one another. This is so remarkable in the genus Verrnetus, that its most proper place would seem to be among the Serpulacex; but the shell is not attached to a foreign body, being commonly twisted together; and the animal is altogether different, not being of the annulated order, but a true mollusc. Jour. Science.

\section{VERMETUS.}

GENERIC CHARACTER: Shell thin, tubular, loose spiral, adhering by the spire. Aperture orbicular, margins united. Operculum cartilaginous.

* V. INTORTUS. Vermiculum I. Mont. Test. Brit., vol. 2, p. 520, Flem. Brit. An., p. 233. Not uncommon.

V. PERFORATUS. Verniculum P. Mont. 'Test. Brit., vol. 2, p. 519. "We have found it in Cornwall, and sometimes with the small interior compartment worn off which gives it the appearance of being naturally perforated." Montagu.

$$
\text { SC'ALARIA. }
$$

GENERIC CHARACTER: The shell subturreted, spire more or less elongated. the last whorl rather larger than the 


\section{6}

next preceding; ribs longitudinal, elevated, interrupted, subacute. Aperture nearly round; the margins circularly united, and terminated by a thin curved wart.

- S. Clathrus. Turbo C. Turt. Lin. Pen. Brit. Zo., vol. 4, pl. 81, fig. 111: A. Stew. Elem., vol, 2, p. 408. Mont. Test. Brit., rol. 2, p. 296. Borlase, Nat. Hist. Corn., pl. 28, fig. 9. Scalaria C. Flem. Brit. An., p. 310. Rare. I have obtained it from Hannafore, near Looe, and from the Land's-end.

* S. ClathratuluS, Turbo C. Turt. Lin. Mont. Test. Brit., rol. 2, p. 29\%. Sc. C. Flem. Brit. An., p. 311. Rare. I have only seen it from near tho Land's-end.

S. TURTONI. Flem. Brit. An., p. 311. The only specimen $\mathbf{L}$ have seen, and which was obtained at Falmouth, differs in some respects from the description given by Fleming. The length is about an inch: the lower whorl less inflated than in Sc. Clathrus, tapering regularly to the point. Ribs twelve, flat, and of various sizes, not continuous across the line of separation: so that few of them on the next whorl, are exactly opposite those of the former, and even the number on each varies. Colour pale brown, with two or three darker spiral bands.

\section{TURBINACEA.}

The shell turreted or conoidal, aperture round or oblong, not dilated; the margins disunited. When placed on their base, the axis is always more or less inclined, never vertical. Journ. Science.

\section{TROCHUS.}

GENERIC CHARACTER: The shell conoidal, spire elevated, sometimes rather depressed; the circumference somewhat angular, often thin. Aperture transversely depressed; margins disunited above. Columella arched, somewhat prominent at the base. An operculum.

* T. ZIZIPHINUS. Turt. Lin. Pen. Brit. Zo., vol. pl. 80, fig. 103. Borlase's Nat. Hist. of Corn., pl. 28, fig. \%. Mont. Test. Brit., vol. 1, p. 274. Stew. Elem., vol. 2, p. 406. Flem. Brit. An., p. 323. Common, near low water mark. When altogether without colour, it has been regarded as a distinct spccies, under the name of $T$. Lyonsii.

T. PAPILlost'S. T. Tenuis. Mont. Test. Brit., 1, p, 275, pl. 10, fig. 3. T. P. Flem. Brit. An., p. 323. Rare. I obtained two specimens from Falmouth: one of them, with the animal, was simply conical, and of small size, the other, found on the shore dead, is about the size of ordinary specimens of $\mathrm{T}$. Ziziphinus, and of more de- 
pressed form than the younger one, in consequence of the expansion of the lover whorl.

* T. EXASPeratus. Pen. Brit. Zo., vol. 4, p. 126. T. Exiguus. Mont. Test. Brit., vol. 1, p. 27\%. T. E. Flem. Brit. An. p. 233. Rare. Dr. Maton found it near the Land's-end.

* T. STRIATUS. Turt. Lin. Mont. Test. Brit., vol. 1, p. 278. Flem, Brit. An., p. 323. Local. Montagu found it in abundance in sand at Falmouth.

* T. CRASSUS. Turbo Lineatus. Turt. Lin. Trochus C. Mont. Test. Brit., vol. 1, p. 281. Stew. Elem., vol. 2, p. 406. Flem. Brit. An., p. 322. Abundant.

* T. MAgUS. Turt. Lin. Pen. Brit. Zo., vol. 4, pl. 80, fig. 107. Mont. Test. Brit., vol. 1, p. 283. Stew. Elem., vol. 2, p. 405, Flem. Brit. An., p. 321. Common.

* T. UMBILICATUS. Turt. Lin. Pen. Brit. Zo., vol. 4. pl. 80, fig. 106. Mont. Test. Brit., p. 286. Flem. Brit. An., p. 322. Common.

* T. CINERARIUS. Turt. Lin. Pen. Brit. Zo., vol. 4, p. 127. Mont. Test. Brit., vol. 1, p. 284. Flem. Brit. An., p. 322. Common.

TURBO.

GENERIC CHARACTER: The shell conoidal or subturreted; the circumference never compressed; aperture entire, round, not modified by the next but last whorl; margins disunited above. Columella arched, flattened, not truncated at the base. An operculum.

*'T. LITTOREUS. 'Turt. Lin. Pen. Brit.Zo., vo. 4, pl. 81, fig. 109. Stew. Elem., vol. 2, p. 40\%. Mont. T'est. Brit., vol. 2, p. 301. Flem. Brit. An., p. 298. Wrinkle, Periwinkle. Common, and abundantly used as food.

* T. RUDIS. Turt. Lin. Mont. Test. Brit., vol. 2, p. 304. Common, but less abuntant than the last. It also keeps more in harbours, and higher on rocks, so as to be left exposed by the tide for many hours, indeed in many instances they are so far removed above the influence of even the highest tides, that nothing but the spray of the seacan reach them. The young are produced alive, about midsummer.

* T. MAMMillatus. Flem. Brit. An., p. 299. "Ac. cording to a memorandum in the handwriting of Da Costa, annexed to one of the specimens figured by Donovan, this shell has been found by Mr. Plati on the Scilly rocks." Fleming. Amongst the shells furnished to me by the kindness of Mr Curnow of Newlyn, I find three specimens from the Land's-end.

\section{SKENEA.}

GENERIC CHARACTER: Spire depressed, and des. titute of spinous processes. Flening. The form of the 
shell is depressed, almosi like that of Valvata; the whorls appearing both above and below. The form of the animal fixes them in this family.

SK. DEPRESSA. Helix D. Mont. Test. Brit., vol. 2, p. 439 , pl. 13, fig. 5. S. D. Flem. Brit. An. p. 313. About low water mark, on sea weed, and perhaps comnon; but from its small size overlooked.

\section{CINGULA.}

GENERIC CHARACTER: The shell ohlong, turreted, pointed; spire long, with numerous whorls; aperture round or oval, pointed posteriorly, dilated anteriorly; outer lip slightly thickened, emarginated; operculum horny.

This genus is denominated Cingula by Dr. Fleming, and Rissoa by Freminville as quoted by Sowerby (Conchological Manual), from whom the generic character is derived; and who observes, they are considered by some authors as resembling Melaniæ (of Lamarck), but placed by Sowerby near the Scalariæ.

* C. STRIATULA. Turbo S. Turt. Lin. Mont. Test. Brit. vol. 2, p. 306, pl. 10, fig. 5. C. S. Flem. Brit. An., p. 30j. In shell sand; when on places on the coast where the eddy is favourable, the smaller shells comprized in this and the neighbouring genera are preserved, when the larger species are dashed to pieces. Montagu found it at Falmouth.

* C. CostatA. Turbo C. Turt. Lin. Mont. Test. Brit., vol. 2, p. 311 , pl. 10, fig. 6. C. C. Flem. Brit. An., p. 305. In shell sand, not uncommon.

* C. PARVA. Turbo Aereus, Turt. Lin. T. Parvus. Mont. Test. Brit., vol. 2, p. 310 . C. P. Flem. Brit. An., p. 306. Montagu found it abundant at Falmouth and the Lands-end. It seems to be common on all our south coast.

* C. STRIATA. Turbo S. Turt. Lin. Mont. Test. Brit., vol. 2, p. 312. C. S. Flem. Brit. An., p. 307. Common in pools of the rocks, among the roots of the smaller sea weeds, and corallines.

C. BRYEREA. Turbo B. Turt. Lin. Mont. Test. Brit., vol. 2, p. 313, pl. 15, fig. 3. C. B. Flem. Brit. An., p. 307. It is introduced because Montagu seems to intimate its occurrence in Cornwall.

* C. CIMEX, Turbo C. Turt. Lin. Mont. Test. Brit., vol. 2, p. 315. C. C. Flen. Brit. An., p. 305. Rare. I have obtained two specimens from near the Land's-end. Montagu found it at Falmouth.

* C. ULVA. Turbo U. Turt. Lin. Pen. Brit. Zo., vol. 4, pl. 86, fig. 120. Mont. Test. Brit., vol. 2, p. 318. C. U. Flem. Brit. An., p. 308 Common. 
" C. PUlluS. Turbo P. Turt. Lin. Mont. Test. Brit, vol. 2, p. 319. C. P. Flem. Brit. An., p. 308. Common.

* C. RETiculata. T. Punclura. Mont. Test. Brit., vol. 2, p. 320, pl. 12, fig. 5, and T. Reticulatus, p. 322 : the latter supposed to be the older state. 'T. R. Turt. Lin. C. R. Flem. Brit. An., p. 306. Not uncommon in shell sand, near Looe.

C. RUBRA. Turbo R. Mont. Test. Brit., vol. 2, p. 320. Turt. Lin. L. R. Flem. Brit. An., p. 308.

Montagu says "we found this species at Whitsand-bay in Cornwall, and with it a shell in every respect like, but in colour, which is perfectly white, and so transparent that the whole of the columella may be seen through the shell."

C. VITREA. 'I'. Vitreus. Mont. 'Test. Brit., vol. 2, p. 321. pl. 12, fig. 3. C. V. Flem. Brit. An., p.308. In shell sand, near Looe.

* C. QUADRIFAisciata. Turbo Q. T. Vinctus. T. Canalis. Mont. Test. Brit., vol. 2, p. 307, 309, 328. C. Q. Flem. Brit. An., p. 299. In shell sand along our south coast.

C. INTERRUPTA, Turbo I. Turt. Lin. Mont. Test. Brit., vol. 2, p. 329. C. I. Flem. Brit. An., p. 308. On the south coast, in shell sand.

* C. CINGILlaA. Turbo C. Mont. Test. Brit., p. 328. C. C. Flem. Brit. An., p. 309. On the south coast, in shell sand.

C. FULGIDA. Turbo F. Mont. Test. Brit., vol. 2, p. 332. Found in sand by Montagu.

* C. LABIOSA. Turbo L. Mont. Test Brit., vol. 2, p. 400 , pl. 13, fig. 7. C. L. Flem. Brit. An., p. 307. Not uncommon.

\section{PHASIANELLA.}

GENERIC CHARACTER: The shell ovate or conical, solid; aperture entire, oval longitudinal, round at the lower part and contracted at the upper; lips disunited above, the right sharp, not reflected. Columella sinooth, compressed, attenuated at the base. Operculum calcareous or horny.

* P. POLiTA. Helix P. Mont. Test. Brit., vol. 2, p. 398. Turbo P. 'Turt. Lin. P. P. Flem. Brit. An., p. 391. Obtained sparingly along our south coast from the Land'send. I have found it with the animal in crab-boats; which shows it to inhabit in from five to ten fathoms.

* P. PALlid A. Turbo P. Mont. T'est. Brit.,vol. 2, p. 325. P. P. Flem. Brit. An., p.302. In shell sand near Looe.

TURRITELLA.

GENERIC CHARACTER: The shell turreted, not pearly; aperture rounded, entire; the margins disunited 
at the upper part; a sinus in the riglit lip. Operculum horny.

* T. TEREBRA. Turbo T. Turt. Lin. Pen. Brit. Zo., vol 4, pl. 81, fig. 113. Mont. Test. Brit., rol. 2, p. 293. Turritella T. Flem. Brit. An.,p. 302. Sparingly along the south coast, from the Land's-end.

* T. FLEGANTISSIMA. Turbo E. Mont. Test. Brit., vol. 2, p. 298, pl. 10, fig. 2. Turritella E. Flem. Brit. An., p. 303. Montagu found it not uncommon in sand from Falmouth harbour, and I have obtained it from the Land's-end.

T. NITIDISSIMA. Turbo N. Mont. Test. Brit., vol. 2, p. 299, pl. 12, fig. 1. Flem. Brit. An., p. 304. Montagu found it in sand from Falmouth harbour.

T. UNICA. Turbo Albidus. Turt. Lin. T. U. Mont. Test. Brit., vol. 2, p. 299, pl. 12, fig. 2. Turritella U. Flem. Brit. Ann., p. 303. Rare. In sand from Falmouth, by Montagu.

\section{CANALIFERA.}

The shell with a canal, variable in length, at the base of the aperture, the right margin of which does not alter by age. An operculum. The first division, with no constant wart on the right lip.

\section{CERITHIUM.}

GENERIC CHARACTER: The shell turreted, aperture short, oblong, oblique, the bottom ending in a short or curved canal, never notched. A slight channel at the upper extremity of the right lip. Operculum small, roundish, horny.

C. COSTATUM. Strombus C. Mont. Test. Brit., vol. 1, p. 225. C. C. Flem. Brit. An., p. 35\%. Very rare. Da Costa found it in Cornwall.

* C. LIMA. Murex Reticulatus. Mont. Test. Brit., vol, 1, p. 272. Terebra R. Flem. Brit. An., p. 346 . C. Lima, Mr. Forbes: a specimen kindly named by him for me. It is abundant in shell sand near Looe, Fowey, and from the Land's-end; but I have no where seen it so large as on a heap of sand from the river below Truro.

PLEUROTOMA.

GEVERIC CHARACTER: The shell turreted or fusiform, ending below in a straight canal, more or less lengthened; a fissure in the upper part of the right lip.

* P. SINUOSA. Murex S. Mont. Test. Brit, vol, 1, p. 264. Flenı. Brit. An., p. 354. In shell sand, near Looe, and from the Land's-end.

FUSUS.

GENERIC CHARACTER: The shell somewhat spindleshaped, channelled at the base, swelling in the middle or below; no external protuberances; spire elevated and 
lengthened; no fissure in the right lip. Columella smooth. Operculum horny.

F. CORNEUS. Murex C. Turt. Lin. Pen. Brit. Zo., vol. 4, pl. 76, fig. 99. Mont. Test. Brit., vol. 1, p. 258. F. C. Flem. Brit. An., p. 348. I have only met with one specimen, which was taken in a trawl at Falmouth.

* F. DEs PECTUS. Flem.Brit. An., p. 349. Not common.

* F. PURPUREUS. Murex P. Mont. Test. Brit., vol. 1, p. 260 , pl. 9, fig. 3. F. P. Flem. Brit.. An, p. 350. Scarce. In shell sand on the south east coast.

F. LINEARIS. Murex L. Mont. Test. Brit., vol. 1, p. 261 , pl. 9, fig. 4. F. L. Flem Brit. An., p. 350. Scarce, in shell sand.

* F. MURICATLS. Murex M. Mont. Test. Brit., vol. 1, p. 262, pl. 9, fig. 2. F. M. Flem. Brit. An., p. 351. Scarce, in shell sand on the south east coast, and near the Land's-end.

F. Costatus. Murex C. Mont. Test. Brit., vol. 1, p. 265. F. C. Flem. Brit. An., p. 349, Rare, in shell sand.

F. ATTENUATUS. Murex A. Mont. Test. Brit., vol. 1, p. 266 , pl. 9, fig. 6. F. A. Flem. Brit. An., p. 350. Rare, in shell sand.

F. NEBULA. Murex Acuminatus. Pen. Brit. Zo., vol. 4, pl. 79. M. N. Mont. Test. Brit., vol. 1, p. 367. F. N. Flem. Brit. An., p. 360. Found at Falmouth by Montagu.

* F. SEPTANGULARIS. Murex S. Mont. Test. Brit., vol. 1, p. 268, pl. 9, fig. 5. F. S. Flem. Brit. An, p. 350, In shell sand, from the Land's-end along the south coast, not uncommon.

\section{TRITON.}

GENERIC CHARACTER: The shell oval or oblong, channelled at the base; the prominences either alternate or rare, or nearly solitary, and never forming a longitudinal row; aperture oblong. An operculum.

Sometimes the Triton has only one prominence, on the right lip, which is never wanting. 'These prominences are never spinous.

* T. ERINACEUS. Murex E. Turt. Lin. Pen. Brit. Zo., vol, 4, pl. 76, fig. 95. Stew, Elem., vol. 2, p. 403. T. E. Flem. Brit. An., p. 356. Common, though scarcely abundant. Young shells differ in having the outer lip comparatively thin, and the pillar narrow.

\section{ALA TA.}

The shell with a more or less lengthened canal at the bottom of the aperture, the right lip of which changes its form with age, and has a sinus at the lower part. 
ROSTELLARIA.

GENERIC CHARAC'TER: The shell spindle shaped or subturreted, ending in a beak shaped canal; right lip entire or toothed, more or less dilated with age; a sinus near the canal.

* R. PES PELECANI. Strombus P. P. Turt. Lin. Pen. Brit. Zo., vol. 4, pl. 75. Stew. Elem., vol. 2, p. 402. Mont. Test. Brit., 1, p. 25:3, R. P'. P. Flem. Brit. An., p. 359. Not uncommon. No animal seems to be better protected from harm, than this; and yet I have obtained it, of full growth, from the stomach of a species of starfish (Asterias Papposa) of no large size. When the soft portion has been digested, the empty shell is rejected, and thus becomes the habitation of the Sipunculus Strombus; which formes a nest for itself by narrowing the entrance with agglutinated sand.

\section{PURPURIFERA.}

The shell with a short canal ascending posteriorly, or an oblique notch or half canal at the botlom of the aperture; directed towards the back. Columella flattened, pointed at the base.

\section{PURPURA.}

GENERIC CHARACTER: Shell oval, smooth, tubercular or angular; aperture dilated, the lower part terminating in an oblique subcaniculated notch. Columella flattened. pointed at the base.

* P. LAPILlus. Buccinum L. Turt. Lin. Pen. Brit. Zo., vol. 4, pl. 72, fig. 89. Borlase's Nat. Hist. of Corn., pl. 28, Mont. Test. Brit., rol. 1, p. 239. Stew. Elem., vol. 2, p. 401. P. L. Flem. Brit. An., p. 341.

Montagu has rightly observed that this common shell is subject to much variety; but it may still be questioned whether two species have not been confounded together. The most common is that given in the references as above, and of which Pennant has engraved a figure, on the left side of his plate, below fig. 88 . It varies in having the channel more or less extended; in the outer lip, which is sometimes strongly tuberculated within; and even sometimes with tubercles on the columella; whereas in other instances it is but slightly waved, as represented in P'ennant's other figures. The general colour is a faint greenish yellow; but some are white, or very dark; or again, with a single or double encircling yellow or black bands. Young specimens are marked with circular concave thin ridges; which in the course of time are rubbed off by the friction which the shell receives from the violence of the waves. The other variety or species, has the lower whorl much more globose, the chief expansion 
occurring at a different part of its surface, from that of the former. The spire also is more obscure, of less proportionate diameter, and with fewer revolutions. The canal is shorter and less deflected: the replication covering a greater portion of the columella. It is suliject to similar variety in the tubercles of the outer lip; but they are fully formed only in advanced age. The colour is usually much brighter than that of P. L; but it is sometimes banded, as in that species. Although from injury received in growth, specimens of $P$. Lapillus may be sometimes found, which approach somewhat nearly to the other, yet in well formed specimens the differences are so great as to leave little room for doubt of their being distinct. I have seen three specimens of this animal, with the extremity of their shells inserted under that of a common Limpet, and feeding on its flesh.

\section{BUCCINUM.}

GENERIC CHARACTER: The shell oval or ovate, conical. Aperture longitudinal, with a notch at the base; but no canal. Columella not flattened, turgid at the upper part.

Lamarck had separated into a distinct genus, under the name of Nassa, those which have a callous columella; but he has since reunited them to the Buccina.

* B. UNDATUM, and B. STRIATUM. Turt. Lin. Pen. Brit. Zo., vol. 4, pl. 73, and pl. 74. Stew. Elem., vol. 2, p. 401. B. U. Mont. Test. Brit., vol. 1. p. 237. Flem. Brit. An., p. 342. Common in moderately deep water, and often taken up attached to fishermen's lines. It is frequently devoured by the Scate, the animal with the operculum attached being found in its stomach; but it seems that the shell is speedily rejected, and in this state it affords an habitation for the Hermit Crab: the largest specimens of which are commonly found in these shells. A curious net work of membranous capsules, sometimes as large as the clenched fist, found on the shore after stormy weather, is the case in which the spawn of this animal is produced. In their original state, they are attached to stones or shells; and when washed on shore, often contain the young shell, which differs much from the adult shape.

* Beticulatum. Turt. Lin. Pen. Brit. Zo., vol. 4, pl. 72, fig. 88, and 92. Mont. Test. Brit., vol. 1, p. 240. Stew. Elem., vol. 2, p. 401. Nasa R. Flem. Brit. An., p. 340. Common, between the tide marks.

B. LINEATUM. Turt. Lin. Mont. Test. Brit. vol. I, p. 245. Flem. Brit. An., p. 344. Da Costa found it in Cornwall. 
* B. INCRASSATUM. B. Minimum. Turt. Lin. B. Minutum. Pen. Brit. Zo., vol. 4, pl. 79, inner angle beneath the left hand. B. Macula. Mont. Test. Brit., vol. 2, p. 241, pl. 8, fig. 4. Nasa I. Flem. Brit. A., p. 340. Common.

Naturalists seem to have overlooked, or considered perhaps as a younger state, of this shell, one that seems to have good clains to be regarded as a distinct species. Its general form is like that of $B$. I. but the whorls and ribs have a more inflated appearance. This is more especially the case with the outer lip, which, viewed from above, shews more dilated; but observed below, that which in the one is more solid and tuberculated, is in the other hollowed out, inflected and thin : leaving the aperture more than twice as large, in shells of equal magnitude. The outer edge is also more circular, advances further up the whorl, and closes more over it. There is no plait over the columella, the fillar of which is less solid, and without the perpendicular line seen on B. I. The substance also is more thin. It is scarcely common, but occurs in similar situations with the other, along our coast.

B. BREVE? A small shell which answers best to the obscure species referred to by Montagu, vol. 1, p. 2.50, and by Fleming, p. 344, as described by Waiker under this name, is among the small collection I was favoured with by Mr. Curnow of Newlyn; who obtained it near the Land's-end. The length of the specimen is about a line; the greatest breadth something less. The whorls five, rounded, separated by a well marked division; summit rather blunt; upper whorls smooth, perbaps from having been rubbed: the two lower whorls prominently ribbed: the ribs wide, high, regular, rounded: those on the lower whorl ending on a circular rib, which begins at the union of the outer lip with the body, and passes round obliquely downward. This lower whorl is proportionately large; aperture moderate, outer lip simple, canal short, and formed as in the genus Nasa of Fleming. Colour white.

\section{TEREBRA.}

GENERIC CHARACTER: The shell lengthened, turreted, very pointed above, aperture longitudinal, many times shorter than the spire, and notched at the hinder part of the base. Bottom of the Columella twisted or oblique.

T. PERVERSA. Turbo Punctatus. Turt. Lin. Murex Adversus. Mont. Test. Brit, rol. 1, p. 271. T. P. Flem. Brit. An., p. 347. Montagu found it sparingly.

\section{COLUMELLARIA.}

No canal at the base of the aperture; but a more or less distinct subdorsal notch, and plaits on the columella. 
VOLUTA.

GENERIC CHARACTER: The shell oval, more or less inflated; apex blunt or papillary; the base notched; no canal. Columella plaited; the plaits parallel, transverse, the lower smallest; columellar lip thin and formed on the pillar.

V. CATENA TA. Mont. Test. Brit., vol. 1, p. 236. Flem. Brit. An., p. 333.

Montagu acknowledges his obligations to Mr. Swainson for all he knew of this shell. 'The latter gentleman's observations are, "I never found this shell alive; I got three or four dead specimens, in the sediment at the bottom of pools of water (if they may be so called) left in the holes of the rocks in St. Anstle bay, near Fowey; have heard of its being taken off the Lizard, and also at Penzance."

\section{MARGINELLA.}

GENERIC CHARACTER: The shell ovate oblong, smooth; spire short; right lip thickened on the outside; base of the aperture scarcely notched; plaits on the columella nearly equal.

* M. VOLUTA. Cypræa V. Mont. Test. Brit., vol. 1, p. 203, pl. 6, fig. 7, and Bulla Diaphana, Mont. Test. Brit., vol. 1, p. 225 , pl. 7, fig. 8 .

Montagu found a mutilated specimen of his Bulla Diaphana, now judged to be the former species in its younger state, at Falmouth; and I have obtained specimens of both states from the Land's-end. The difference between M. V. and B. D., is so great, that close observation of many individuals is necessary to prove them the same.

\section{VOLVARIA.}

GENERIC CHARACTER: The shell cylindrical, convolute; spire scarcely projecting; aperiure narrow, the length of the shell. One or more folds on the lower part of the columella.

V. PALLID A. Voluta P. Turt. Lin. Mont. Test. Brit., vol. 2, p. 232. V. P. Flem. Brit., An., p. 333. Crouch's Intro., pl. 19, fig. 15. Very rare.

\section{CONVOLUTA.}

The shell without a canal, but having the base of the aperture chanelled or efluse; the whoris large, compressed, convolute, the last nearly covering the whole of the others.

$$
\text { CYPRAA. }
$$

GENERIC CHARACTER: The shell oval, or ovate oblong, convex; the lips curred inwards; aperture loncitudinal, narrow, toothed on both sides, the extremities effuse. Spire very small, hardly perecptible. 
* C. EUROPAA. C. Pediculus. Turt. Lin. Borlase's Nat. Hist. Corn., pl. 28, fig. 12. Stew. Elem., vol., 2, p. 397. Mont. Test. Brit., vol. 1, p. 200. C. E. Flem. Brit. An., p. 330. In its young state this is altogether unlike the perfect shell, and constitutes the C. Bullata of Montagu, Test. Brit., vol. 1, p. 202, pl. 6, fig. 1 . In this condition they differ greatly in size; but whatever be the magnitude obtained, the further progress towards the perfect markings is not accompanied with enlargement : so that many matured shells are much smaller than others in their first growth. When the form and striation are in the intermediate state, they constitute the Cypræa Arctica of Montagu, vol. 1, p. 201. These changes are rapidly passed, and take place about the end of summer. Common, and often found with the animal, in crab-boats. Cornish specimens are usually smaller than those farther east.

\section{CEPHALOPODA.}

\section{POLYTHALAMOUS CEPHALOPODA.}

The shell many chambered, more or less enveloped, placed on the hinder part of the body of the animal, often adhering.

\section{FIRST DIVISION.}

The shell many chambered, the partitions simple; not showing any divided sinuous sutures on the inner surface of the shell.

\section{ORTHOCERATA.}

The shell straight or nearly so; not spiral.

\section{ORTHOCERA.}

GENERIC CHARACTER: The shell straight or slightly arched, subconical, striated on the outside by numerous longitudinal ribs; chambers formed by transverse partitions, perforated by a central or marginal tube.

O. IMPERFORATA. Dentalium I. Turt. Lin. Mont. Test. Brit., vol. 2, p. 496. O. I. Flem. Brit. An., p. 237. Found by Montagu in sand at Falmouth.

o. RECTA. Nautilus Rectus. Mont. Test. Brit., vol.1, p. 197. O. R. Flem. Brit. An., p. 236. Usually considered exceedingly rare; but in a few instances I have found it adhering to the shell of a Pinna from deep water, and suppose it not uncommon, though from its small size commonly overlooked.

LITUOLATA.

The shell partly spiral, the last whorl continuing in a straight line. 
SPIRULA.

GENERIC CHARACTER: The shell cylindrical, thin, nearly transparent, many chambered, partly turned into a discoidal spiral form; the whorls separate, the last produced in a straight line. Partitions transverse, equally distant, externally concave; syphon lateral, interrupted; aperture round.

* S. AUSTRAlis. Nautilus Sp. Turt. Lin. Sp. A. Flem. Brit. An., p. 227. Crouch's Intro., pl. 20, fig. 7. According to Dr. Fleming, two specimens only of this shell are recorded as British; having been found on the coast of Ireland. I have been informed of sereral, taken on the coast of Cornwall, and three specimens have come into my possession, that were found within a mile of my own residence; but they were destitute of an inbabitant, and one is shewn to have been for some length of time dead, by having attached to it the shell of a small Spirorbis. They were probably floated to us in the same manner as the Ianthina, as before noticed; and whether the animal has lived in our waters is still a matter of doubt.

The Secoxd Drvisiox includes no British Shell.

\section{A P P E N D IX.}

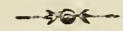

REPORT on the Zoology of the County of Cornwall, presented (with some alteration) to the Meeting of the British Association of Science, at Phymouth, in the year 1841, forming an appendix to the preceding Fauna.

The Report of the Zoology of the County of Cornwali now presented to the British Association of Science, is designed to afford a summary of the species, chiefly of the Vertebrate, Radiate and Testaceous classes, with the stalk eyed genera of Crustaceans, and so many of the Zoophytes as have been recognized by naturalists: reserving for further consideration the species concerning which there is any doubt. It is intended also to comprize such as have been discorered since the publication of the former portion of the Cornish Fauna.

Of the fourteen or fifteen species of Cheiroptera (Bats) enumerated as British by Mr. Bell, six are included in the Cornish Fauna; and one more (Vespertilio Discolor) has been found at no greater distance than Plymouth. Of the remainder, eight are too limited, in numbers and destribution, 
to enter into a calculation of comparison with other parts of the kingdom. The commonest of the Cornish Bats are, the Pipestrell, Lesser Horse-shoe and Long-eared, in the order in which they are enumerated; but their local occurrence depends more on the accident of their meeting with congenial haunts, than on the mere influence of climate. 'The latter circumstance, however, produces its effect on the habits of these animals; so that in Cornwall, where what may be denominated severely cold winters do not occur more frequently than in cycles of six or eight years, the appearance of the Bat may be witnessed in every week, in an ordinary year. A fall below the 40 th degree of the thermometer is the signal for their retreat; but a slight change to a milder temperature restores them to activity, when not uncommonly they may be seen at mid-day, in search of prey, which might not be obtained at the more usual hours of the evening.

It may be regarded as another proof of the mildness of the climate, that the Longtailed Field Mouse (Mus Sylraticus) breeds at, or even before, the beginning of January; forming its nest at this time in ricks of hay. The Frog also is rarely later than this period in depositing its spawn.

Of the genus Sorex, Cornwall possesses three species, sufficiently distinguished. These are, Sorex Araneus, Jenyns in the Magazine of $\mathbb{Z} o$ ology, vol. 2: the front teeth a deep brown through most of their length; Bell's British Quadrupeds, p. 109. Another species, S. Araneus of Duvernoy and Jonyns, Mag. of $\mathbb{Z}_{0}$., vol. 2, fig. 1, the snout not so long as in the $\mathbf{S}$. Araneus of English Authors: the body and tail longer; ears and tail different, the former being more membranous, and very slightly furred; the teeth brown only at the tips of the lower front teeth; and so generally of the molars; tail narrow at the commencement; slightly haired, and none beyond the tip. A third species is referred to $S$. Fodiens of Bell, p. 115; S. Bicolor of Jenyns, Mag. of Zo., vol. 2, p. 37; but it differs in some particulars which may require notice. Weight three drams, fifty-six grains; length of the body three inches, of the tail one inch and three quarters. Nose somewbat flattened; hind feet and toes ciliated, the fore feet less so. Under front teeth purely white; the upper slightly coloured; their crenations not exactly like any in Mr. Jenyns' plate.

Of Quadrupeds now extinct, but which formerly ranged our liiils, beside tise Deer, of which the horns are often found in stream-works, and of which examples exist in the Museum of the Royal Institution at Truro, and in that of the Royal Geological society at Penzance, remains have been found of a large animal of the Ox kind, and which I feel no scruple in referring to the Bonassus described by Pliny, Lib. 8, C. 15, as in his day inhabiting the north of Europe. A 
gentleman has informed me that within his knowledge, the skull of this animal, with the horns affixed to it, was found at the depth from the surface of sixty feet, in the Porth Mining works, near Fowey. The horns were of large size, and much projecting forward, as in the Leicester breed of cattle; they belonged to one which, from his judgement of the modern ox, might weigh 1000 pounds. In the collectino of the Royal Geological Society at Penzance is a portion of the Humerus of what appears to have been the same animal, the circumference of the shaft of which measures twelve inches.

Of Birds 230 species are reported in the Cornish Fauna, to which the following must now be added.

HONEY BUZZARD. Buteo Apivorus. Yarrell's Brit. B., vol. 1. p. 85. A bird of the first year, killed in Cornwall, fell into the hands of Dr. Leach, and is now in the British Museum. Mag. Nat. Hist. N. S., vol. 1, p. 539. SNOWY OWL. Strix Nyctea. Yar. Brit. B., vol. I, p. 134. Its occurrence in Cornwall is reported by $\mathrm{Mr}$. Bellamy, Nat. Hist. of south Devon, p. 200. The specimen is in the possession of the Reverend Mir. Hore, where I had an opportunity of inspecting it. It had probably been driven hither by a storm, having suffered much from the weather.

WOOD SHRIKE. Lanius Rutilus. Yar. Brit. B., vol. 1, p. 160. Reported by Mr. Rodd, of Penzance.

BLACK STAR'T. Phænicura Tithys. Yar. Brit. B. vol. 1, p. 241. Reported by Mr. Rodd.

GREY HEADED WAGTAIL. Motacilla Neglecta. Yar. Brit. B., vol. 1, p. 375. Mag. Nat. Hist., N. S., vol. 3, p. 467.

WHITE CROSBILL. Loxia Falcirostra. Yar. Brit. B., vol. 2, p. 38. Reported by Mr. Rodd.

ROSF COLOURED PASTOR. Pastor Roseus. Yar. Brit. B., vol. p. 51. Reported by Mr. Rodd, and Mr. Mitchell.

The MAWMET PIGEON. Columba Turcica. Reported in the Cornwall Gazette, as killed at St. Enoder in August 1840 ; it may probably be no other than a variety of th Common Pigeon: the specimen escaped from confinement. NIGHT HERON. A rdea Nycticorax. Yar. Brit. B., vol. 2; p. 485 . Specimens of the male and female and young bird in nestling plumage have been obtained by $\mathbf{M r}$. Rodd. The male was killed at Crowan; the fermale at or near the Lizard; the young one was caught alive near Newlyn, and appeared to answer in every respect to the Gardenian Heron of authors. Mr. Rodd, report of the Royal Institution of Cornwall, 1839, p. 39. 
DOTTEkEL. Charadrius Morinellus. Yar. Brit. B., vol. 2, p. 392.

SPOTTED REDSHANK. Totanus Fuscus. Yar. Brit. B., vol. 2, p. 520. Reported by Mr. Rodd.

WOOD SANDPIPER. T. Glareola. Yar. Brit. B., vol. 2, p. 534. Reported by Mr. Rodd.

PECTORAL SANDPIPER. Tringa Pectoralis. Yar. Brit. B., vol. 2, p. 654. By Mr. Mitchell.

EIDER DUCK. Anas Mollissima. A female shot on the Looe River, Christmas, 1839.

LONGTAILED DUCK. Harelda Glacialis. A female taken at Penzance, by Mr. Mitchell. West Briton, April, 1840.

ICELAND GULL. Larus Islandicus. Obtained at Hayle in 1840.

WILSON'S PETREL. Procellaria Wilsoni. An account of the first specimen of this bird taken in the British Islands, and which came into my possession, was communicated to the Linnean society; and is published in the 18th vol., of its Transactions, p. 688. The specimen itself has been submitted to Mr. Yarrell's inspection.

The number of Fishes reported in the Cornish Fauna amounts to 167 species: to which the following are now to be added:

LITTLE WIEVER. Trachinus Vipera. Yar. Brit. F., vol. 1, p. 25.

MALARMATE. Peristedion Malarmat. Yar. Brit. F. Sup., p. 10. I am informed by Mr. Peach that two specimens were caught near Gorran, in 1838.

PALM CRESTED BLENNY. Blennius Palmicornis. Yar. Brit. F., vol. 1, p. 283. B. Yarrellii, Valenciennes, and of the 2nd edition of Mr. Yarrell's Brit. Fishes. The specimen, the only one I have seen, measured $7 \frac{1}{4}$ inches in length, and has been sent by me to the British Museum.

POUTASSOU WhitiNG. Merlangus Poutassou, Risso, Ichth. de Nice, p. 115. This, the Whiting of the Mediterranean, and very different from the Whiting of our coast, was taken at Polperro, in May 1840. A figure and detailed description will appear in the second edition of Mr. Yarrell's History of British Fishes.

STRAIGHT NOSED PIPEFISH. Syngnatlus Ophidion. Yar. Brit. F. Sup., p. 47.

The actions of the Syngnathidæ are so rarely observed, that it may be interesting to record the following, of the Snake Pipefish: Syngnathus Ophidion. Yar. Brit. F., vol. 2, p. 338 : in future to be termed S. Anguineus, to avoid confounding it with t'se Straight Nosed Pipefish. Throughout the whole of the summer of 1841, Snake Pipe- 
fishes have abounded in countless myriads, in a manner never remembered by fishermen. All of them were of about one size, 14 or 15 inches in length. They kept at the surface over a depth of 20 or 30 fathoms, and were much preyed on by other fishes. I was much amused by the actions of one that had been left in a deep pool by the receding tide; which actions are descriptive of the mode by which they contrive to suspend themselves at the surface. It laid hold, by its tail, of a piece of loose and slender seaweed, somewhat lighter than the specific gravity of its own body; and assuming the attitude corresponding to that represented in the vignette to Mr. Yarrell's account of the Hippocampi, it steered the seaweed about at pleasure, by the action of its dorsal-fin; the posterior portion of its body being twisted round the weed, the anterior erect and free.

SPINOUS SHARK. Squalus Spinosus. Yar. Brit. F. Sup., p. 54.

Of stalk eyed Crustaceans the Cornish Fauna reports 67 species; to which one or two more will be added, when their synonyms are placed beyond doubt. It may be proper to remark, that Platyonichus Plicatus (M. Edwards' Crust., vol. 1, p. 442, ) has been confounded with the small specimens of more than one kindred species; from which it is not easily distinguished, except by comparing them together. In habits however, it differs considerably ; living in deep water on the surface of which it swims in pursuit of prey. In this respect it imitates the Nifper Crab (Polybius Henslowii); and though so much less in size, with scarcely less powers.

Of Testaceous Mollusks an enumeration is given in the second part of the Cornish Fauna, and it is probable that further research will bring to light many hitherto unknown species. The following additions and remarks are added by way of supplement to the preceeding account of the shells : SERPULA FILOGRANA. This curious mass of interwoven tubes might readily be mistaken for a coral of the Genus Tubulipora; but that the animal is of the class which forms the tubes of the Serpulacer, has been shown in the Zoological Journal, by Mr. Berkely. The shells are closely and somewhat regularly interwoven, many thousands together, forming a mass with many crevices and meshes: the progress of the growth of which must afford an interesting subject of enquiry. My only specimen was thrown on shore in St. Austle-bay.

VERMILIA CORONATA. Length less than an inch, of the size of a small pin; about a fourth of the length erect, round; the orifice having fixed on it a coronet having six prominent equal sized teeth, placed at regular intervals, and diverging straight from the rim. Colour pale yellow. 
On a stone taken up by a fisherman's hook from deep water. It seems to he unknown, and I have therefore given it the name as abore.

The Serpulaceæ appear to be of rapid growth, and at first to be destitute of a shell. I have seen specimens of an Heteroclite species, probably Spirorbis Heteroclita, with the newly formed shell, though of full size, so transparent, that the fine vessels and fibrils of the animal might be examined through its substance.

BALANUS RUGOSUS. Mont. Test. Brit., vol. 1, p. 8. Scarcely uncommon, though local.

A question of doubt(?) should be added to Tubicinella Clavata.

ANATIFERA FASCICULARIS. After a storm in October, 1841, I found on the beach a small enspty phial bottle, with this barnacle attached to its neck; and $\mathrm{Mr}$. Peach informes me that numerous feathers of a bird were at the same time washed on shore, having attached to them, specimens of A. Fascicularis and A. Sulcata : proofs of the fact that these rare species are capable of attaching themselves to substances which have never been deeply immersed. The first named of these species though commonly appearing almost sessile, is capable of elongating its pedicle to about the length of the shell, and of moving it in various directions.

A. ANSERIFERA. Mr. Peach found this species attached to a stem of sea-weed, contrary to its usual habit.

ARCA RHOMBEA. Cornish Fauna, Shells, p. 31. This seems to be A. Tetragona of Mr. Forbes, Fauna Monensis, p. 41, and pl. 3, where it is represented as covered thickly with hairs. The operculum is also stated not to be a constant character.

HELIX SERICEA. Gray's Turton, p. 153, pl. 11, fig. 134. Local, but scarcely uncommon. I have found several specimens in an undisturbed part of my garden.

SIGARETUS TENTACULATUS? a single specimen from Gorran.

Among the Radiate Animals the Cornish Fauna reports 21 species of Echinodermata; but the list will require some correction, and must then be left with the omission of a few unascertained species of Holothuriadæ. The species to be added are :

ECHINUS MILIARIS. Forbes' History of Starfistes, p. 161. Common.

SPATANGUS PURPUREUS. Forbes, p، 182. Not uncommon.

LUIDIA FRAGILISSIMA. Forbes, p. 135. From deep water, scarcely common. 
ASTERIAS AURANTIACA. Forbes, p. 130. It is so rare that I had never seen a specimen, until at the Meeting of the British Association for science, Mr. J. C. Bellamy produced one taken in Whitsand-bay. It is common in Plymouth-sound; and I obtained a few specimens from the Breakwater.

OPHIURA BRACHIATA, must be omitted, until discovered anew.

The following are ascertained Cornish species of Holo. thuriadæ :

CLCUMARIA PENTACTES. Forbes, p. 213.

SYRINX NUDUS, Forbes, p. 245.

SIPUNCULUS BERNARDI. Forbes, p. 251.

THALASSIMA NEPTUNI. Forbes, p. 259. A species of common occurrence from deep water, inhabiting perforations of stone, which it enters apparently for the purpose of devouring the animal of the shell-fish within. Species remaining for examination are chiefly of the genus Cucumaria; logether with one closely allied to the genus Psolus of Mr. Forbes. A notice of it was sent to that Gentleman, but too late for publication in his history of this farnily. It was judged by him to be worthy of generic distinction, which is thus marked: under surface extending through the length, and covered with thickly set suckers, not in distinct rows. Upper surface covered with tuber. cles, each with an orifice, from which at will is protruded a cartilaginous point. Tentacula at the end 18, with clubshaped foliations on slender stalks.

The specimen was about six inches long, and of the size of an ordinary mould candle. Upper surface dark blue; centre of each tubercle light, enclosing a dark point, and round the whole a light purple ring. After death these tubercles sunk and disappeared; so that without pressure they could scarcely be perceived. At that end of the animal opposite the tentacula is an orifice, with a small blunt portruding process; which seems in constant, though slow, action, producing a slight eddy in the water. When alire this creature had a line along its dorsal surface, narrow but free of tubercles; and something similar but shorter, on each side; both disappearing when the animal contracted, and after death. If it be allowed that this creature is entitled to form the type of a new genus, I would propose for it the name of Forbsia, in honour of the Natural Historian of the British Echinodermata.

In this place $I$ would insert an account of an animal, of which a figure was submitted to the inspection of the most emrnent Naturalists and comparative Anatomists, at the 
mecting of the British Association; but concerning which the only conclusion definitely formed was, that the species, and perhaps the genus, was new to Britain, if not to science. It consisted of an oblong mass ten inches in length, seren wide, and about three in thickness, the weight three ounces less than three pounds. The under surface, by a portion of which it had been attached to a solid body, was flat and bare, and of the whole breadth of the animal; but it was not quite the whole length. At the end which I would designate the anterior, was a wide and somewhat deep cavity, but not leading to any organization within; and it is at this part that the flat under surface does not quite reach the extremity. At the left side (counting the anterior end as front) a void space for two thirds of the length, bare and rigid, and on its upper portion an orifice; another in a depression about the middle of the upper surface: the direction running toward one side. Round the margin of the under surface, and irregularly placed on the upper, are a number of lumps or broad tubercles, which are covered and encircled with flaccid processes, that are most numerous on the anterior end. They vary in length from a quarter of an inch to an inch, and a few are bifurcate. If there be any orifice to these processes, it is ninute; but the process is wide, flat, and flaccid; and each has a light coloured vessel, or intestine having yellow or brown contents; and a row of white thick set dots on each side. Colour a leek-green, except the processes, which therefore appear conspicious. This description conveys the idea of an animal of the class Ascidia, and differing from the ordinary form of the known species only in the existence of organized processes. But lissection proves it to belong to a very different genus of the Cuvierian order Acalepha. Instead of having a separate intestine communicating with orifices, the whole of the interior was solid, gelatinous, and only not homogenous by being intersected in all directions with a multitude of fine white threads. Beside the protruding processes, a few also were found inserted in the substance beneath the surface, as if not yet exsertel. Each of these processes contains a stomach or intestine, which penetrates for nearly an inch, swelling as it approaches its greatest depth; and from this part a thread passes into the anterior, anastomosing with others in an inextricable network: at last uniting again to form two black tlureads, one of which passes to each of the orifices already mentioned, in the side and summit. In each of these orifices was a quantity of powdered coralline; but no grittiness could be perceived in any other part of its structure. It seems therefore to become digested in the cavity, and the nutritice part only to be conveyed within. In one part of the interior 
was a small cavity, in which was a gelatinous globule, that escaped on being touched. I suppose it to have heen an ovum. One of the most eminent comparative anatonists of the age was inclined to refer this animal rither to the genus Botryllus or Polyclinum: I think most probably the Latter.

\section{SUMMARY OF CORNISH ZOOPHYTES :}

The ascertained Species compared with the British List contained in the Work on the sulject by Dr. George Johnston.

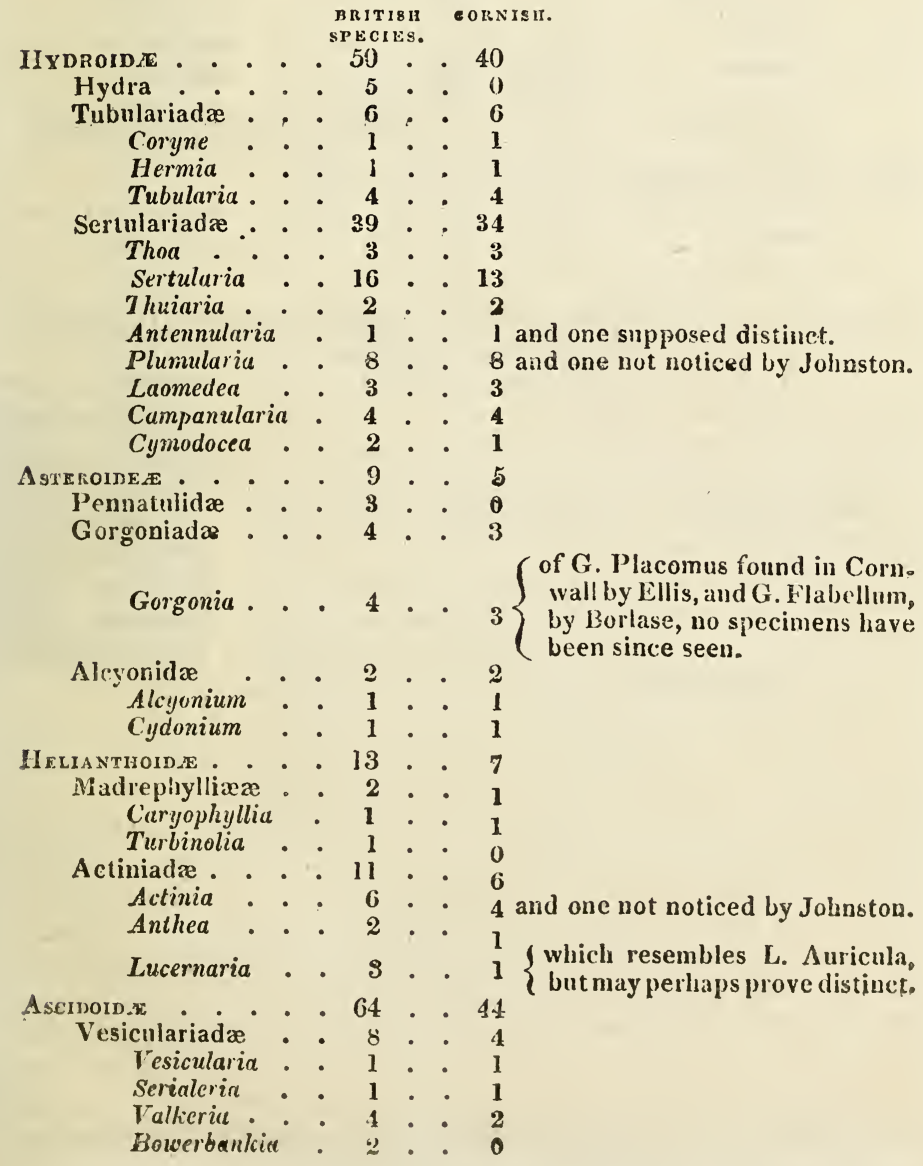




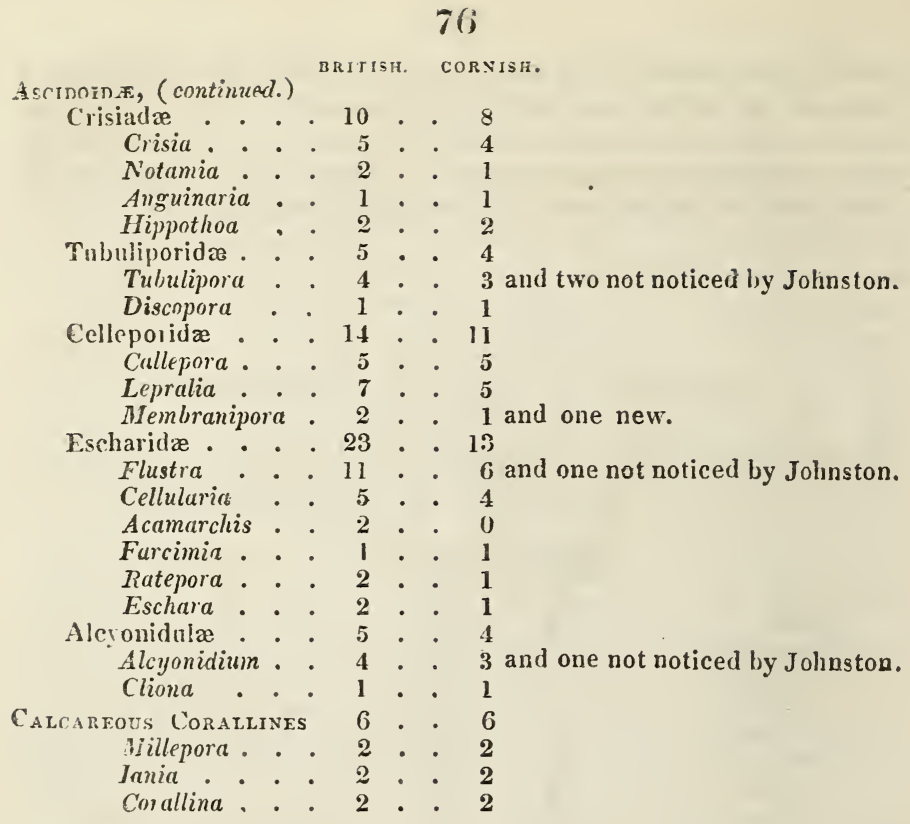

Sexeral species are confounded with each of the kinds included in these Genera of Calcareous Corallines. 


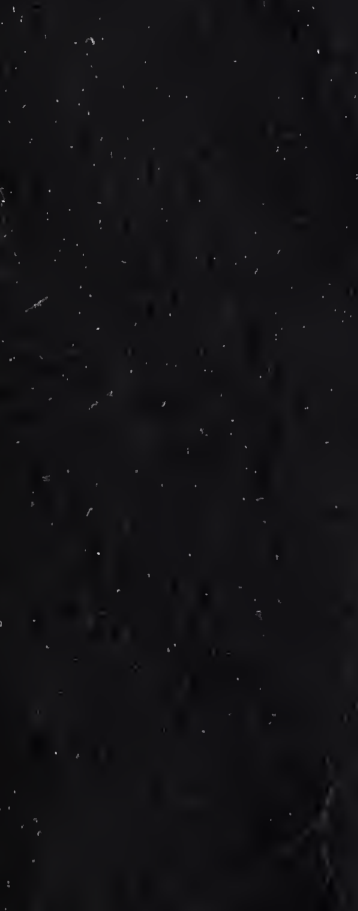




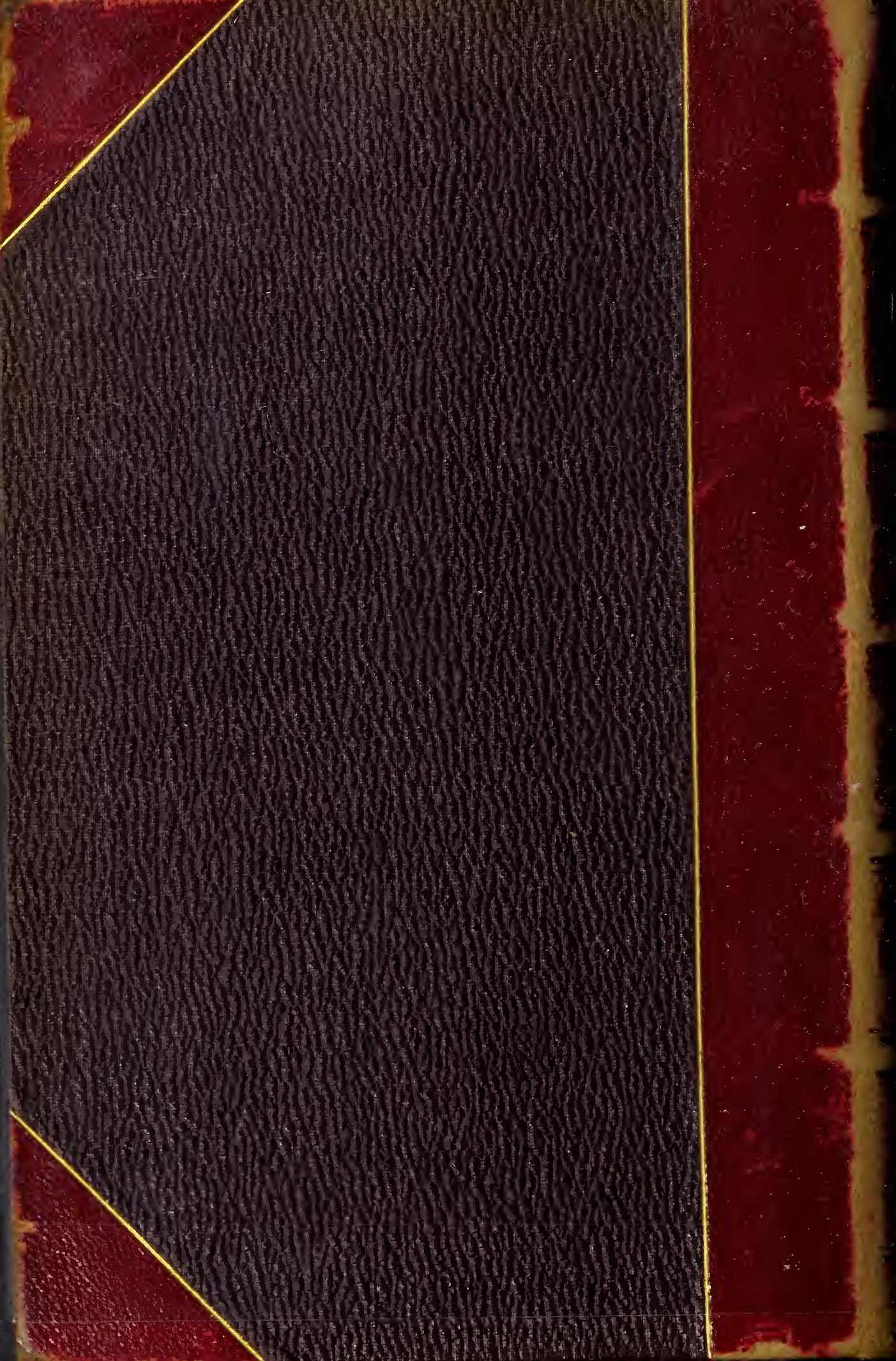

